\title{
Sproglige æudringer.
}

Af Nikolaj Andersen.

\section{II.}

Sproget er det middel, hrorved vi meddeler andre indholdet af vor tænkning. At tænke er enten at sammenfatte enkeltforestillinger til begreber eller at forbinde begreber til domme og slutninger. I begge tilfælle er altså begrebet en fremtrædende enhed.

Den til begrebet svarende enhed i sproget er ordet, der ligesom fastholder hint og bærer det ud til yderverdenen. Ordet er ligesom begrebets legemliggörelse. Jo större mangfoldighed af begreber derfor et menneske er $\mathrm{i}$ besiddelse af, desto flere ord må han have til sin ri̊dighed for på nöjagtig men muligst kortfattet måde at kunne åbenbare sin bevidstheds fylde, medens den, hvis begreber er fa, kun behøver et forholdsvis ringe antal ord for at give sine tanker et tilsvarende udtryk.

Og hvad der således er sagt om den enkelte, gælder tillige for folkeslagenes vedkommende; thi et folke- 
samfund med fallos sprog kan botragtes som et samlingsindividuum, hvis nationale ordforråd i reglen vil svare til dets stïrro eller mindre begrebsrigdom. I al almindelighed vil vi derfor også omvendt kunre drage den slutning, at jo stïrre eller mindre et folkeslags ordforråd er, desto videre oller snævrore må også dets åndelige synskres være. Men jeg siger med vilje i almindelighed; thi sảsnart vi $\mathrm{i}$ særlige tilfexlde vil anstille en sammenligning, støder vi straks på betydelige vanskeligheder.

En sădan vanskelighed ligger bl. a. deri, at to forskellige sprogs betegnelser for de samme begreber langt fra altid dækker hinanden $i$ antal. På den ene side kan nemlig det samme begreb, for hvilket der i det ene sprog kun baves et enkelt særegent udtryk, i et andet som oftest betegnes ved to eller flere jærngyldige. Säledes haves for begrebet "en stav af mådelig længde og tykkelse, især til at støtte sig ved“ j tysk kun det one ord stock, men i dansk både stok og kaep; og omvendt betegnes begrebet "en mand som nærer sig af at slagte kvæg"i dansk ved det ene ord slagter, medens det $\mathrm{j}$ tysk kan gengives både ved schlachter, fleischer og metzger. Pa den anden side forekommer det ikke så sjaelden, at flere begreber, der $\mathrm{i}$ det ene sprog mä gengives ved lige să mange ord, i et andet kan udtrykkes ved en og samme betegnelse. De forskellige begreber f. eks., der i dansk betegnes ved rov, fuks (rød hest), takvinge (sommerfugl), rus (ung student), guldmont, ovnror o. fl. a., kan af tyskerne udtrykkes ved det ene ord fuchs; og omvendt kan de fire forskellige begreber, der i tysk betegnes ved schritt 
(skridt), tritt (indretning på en vogn til at træde p̊, när man stiger op eller ned), sprosse (tværtræ $\mathrm{i}$ en stige) og stufe (vandret flade pă en trappe) på dansk gengives ved det ene ord trin. Men desuden indtræder også undertiden det tilfælde, at et begreb, der $\mathrm{i}$ det ene sprog kan betegnes ved et enkelt ord, i det andet kun kan udtrykkes ved en frase, d. v. s. et af flere ord bestaende led af en setning. Tager vi f. eks. det begreb, der på tysk findes udtrykt $\mathrm{i}$ ordet gebirgsauslïufer, så vil vi finde, at det på dansk vel næppe kan gengives kortere end ved sidegren af en bjoergkeede; eller man tage til gengæeld begrebet "en lyngklædt bakke", for hvilket vi pă dansk jo har ordet lyngbakke, men som pa tysk kun kan udtrykkes ved frasen mit haidekraut bewachsener hügel.

En anden vanskelighed ligger $i$ selve beregningen af ordenes antal $i$ hvert af de enkelte sprog. Ganske vist har vi for de enkelte kultursprogs vedkommende ordboger nok, som enhver, der har tid og tålmodighed, let kan få lov til at tælle i. Men uheldigvis er de fleste af disse ordboger ikke ret egnede til uden videre at tjene som grundlay for en objektiv sammenligning. Det beror i hvert enkelt tilfælde nemlig bade på redkommende ordbogs swrlige formål og forfatterens personlige skön, livor stort et antal ord der er medtaget. Således findes der i Såbys danske retskrivningsordbog henved 30,000 ord, medens tredje udgave af Krapers dansk-tyske hăndordbog efter en loselig beregning indeholder over det dobbelte antal danske ord. Pa tilsvarende made finder jeg i Dudens tyske ortografiske ordbog kun lenved 27,000 tyske ord, men i 
anden udgave af Kapers tysk-danske ordhog ra. 78,000, altså næsten det tredobbelte. Eibes engelsk-danske ordbog byder os rigelig 36,000 og Thieme-Preussers "Wörterbuch der englischen und deutschen sprache" henved 80,000 engelske ord, men "Century Dictionary" anslår tallet af engelske ord til omtrent 200,000 o. s. v. Selvfolgelig kan der indvendes, at man ved en sammenligning bör holde sig til de fuldstændigste ordboger i hvert af de pågældende sprog; men hvor er så grænsen mellem ufuldstændighed og overkomplethed? Enhver, der med nogen opmærksomhed har set $i$ en större ordbog, vil sikkert have fundet adskillige udtryk, som han dels af hensyn til deres forældede præg eller alt for nybagte udseende, dels på yrund af deres udenlandske karakter eller bygdemålsagtige beskaffenhed næppe tör regne til vort nuvierende almindelige nationale ordforråd; og enbver, der liar haft med oversæettelser at bestille, vil omvendt lige så sikkert have gjort den erfaring, at netop de ord, man søger i vedkommende ordbog, som oftest er ondskalssfulde nok til ikke at findes.

Men hrad enten man vil kalde et tungemåls ordforråd stort eller lille $\mathrm{i}$ forhold til andre, så er det $\mathrm{i}$ alt fald $i$ sig en for anderlig störrelse. Thi stilstand kender naturen jo ikke. Enten er der fremskridt eller tilbagegang: redskaberne for den menneskelige virken og genstandene for den menneskelige taenkning må enten forøges eller formindskes. $O g$ denne begrebernes forogelse eller formindskelse medfører ganske naturlig en tilsvarende 
Endring af ordforradet.

I de fleste tilfalde turde det dog vare således, at der hverken er udelukkende fremskridt eller udelukkende tilbagegang, men at ordforrådet beriges i enkelte retninger, medens det samtidig mindskes $\mathrm{i}$ andre.

Holder vi os forst og fremmest til ordforrådets berigelse, sa vil vi ved nærmere betragtning snart få at se, at der med hensyn til indforelsen af nye betegnelser både er fremmede og hjemlige kilder at oso af.

De fremmede kilder er simpelthen andre nationers tungemål. Ved at komme i berering med fremmede folkeslag lecrer vi nye genstande, indretninger og opfattelser at kende, og det ligger da meget nar, at vi til betegnelse af de nye begreber benytter de ord, vi har hort af de fremmede.

På denne måde har vort danske sprog allerede i ældre tider optaget talrige fremmede ord, der er indforte samtidig med de pågxldende begreber.

Navnlig har dette været tilfældet med en stor del ord, der er komne til os over Rom, Lvis mægtige kulturelle indflydelse gennem lange tider har gjort sig gæaldende i de nordiske lande.

Allerede det hedenske Rom har således efterladt enkelte spor i vort sprog.

Dette kan historisk forklares på folgende måde. I de forste ărhundreder af vor tidsregning udbredte romerne efterhainden deres verdenshandel helt op over Nordens grienser og trădte således i uniddelbar forbindelse med vore forfaxdre. Romerske mercateres (kobmænd) drog med deres kister 
og serkke langs Vejksel og Oder til Gulland, Oland og Bornlıolm samt langs Rinen og dernæst videre til Jylland; og fra deres mercatus (handel, handelsplads) har vi da vort marked, sunderjysk mer'ke, ligesom kiste er en umiddelbar overforelse af det latinske cista (dengang udtalt kista, der atter er det græske kistè) og suk af det latinske saccus (grækernes sakkos). Vore forfædre kendte för deres beroring med romerne intet til rede penge: deres kvæg og våben var hele deres formue; men når de solgte noget til de romerske handelsmænd, tik de moneta; og købte de noget, si kostede det moneter. Ordet koste er det latinske constare (komme til at stå, jf. komme dyrt til at stå) og det ligeledes latinske moneta betyder "et præget pengestykke"; vore forfædre udtalte ordet med trykket på forste stavelse, móneta, hvoraf så senere vort mont eller mynt er fremgået. Med romersk mont fülgte også romersk vægt: vort danske pund er det latinske pondus (vægt) eller måske rigtigere en særlig ablativ-form pondo (altså egentlig: i vægt). Blandt de af de omtalte købmænd syd fra medbragte varer skal her blot omtales vin og peber. Vinstokkens fædreland er egnen syd for det kaspiske hav, lıvor også en af de semitiske stammers hovedgrene har hjemme. Herfra udbredte den sig over Syrien og Lilleasien til den græske halvo og derfra til Italien, der snart blev et vinland og allerede $\mathrm{i}$ den her omhandlede periode også sendte prøver af den aedle drik til de nordiske lande. Og med tingen fulgte navnet: hebraisk jajin, arabisk wain, græesk voinos (sencre: oinos), latinsk vinum, dansk vin. Pelheren er kommen til os fra Indien over Persien, 
Grakenland og Italien: sanskritnavnet pipuli blev hos perserne, der ikke kendte $l$, til pipari, hos grakerne til peperi, hos romerne til piper og hos os gennem piparr og pipuer til peber og sonderjysk pefe, hvilken sidste form altså jkke har noget med det höjtyske ifeffer at gïre, da det er en almindelig regel, at ældre dansk $p$ efter vokal i rigsmålet ar blevet til $b$, men i sonderjysk til $f$, som seld. d. tapa, rm. tabe, sj. taf'. At peberen ma have viret et meget yndet kryderi hos de gamle germanske folkeslag, fremgår deraf, at da Vestgoternes konge Alarik i vinteren $40 \mathrm{~s}$ belejrede Rom, forlangte han i brandskat bl. a. 3000 pund peher. Maske ad en mere middelbar vej, ved forplantning fra syd til nord gennem Mellemevropa, har vi over Italien desuden fået et par så hjemlig lydende ord som kål og kat. Vor kål, eller rettere kålstokken, hed hos romerne caulis, der svarer til det græske kavlos (stængel). Tamkatten, der menes at stamme fra Østafrika, var hos de gamle æyyptere et helligt dyr, så helligt, at enhver, der drælite en kat, blev straffet med diden. Grwkerne oy romerne kendte fra begyndelsen af ikke katten som husdyr; dens gerning besergedes af vaselen (græsk galeê), der inidlertid ikke var et rigtigt husdur. Da derfor græekerne senere begyndte at holde katte, betegnedes det fremmede

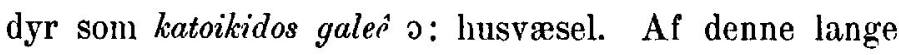
græske betegnelse fremgik si̊ senere den korte latinske catus, som derp̊ ved dyrets og navnets indvandring til os blev til kut alene. Er den omtalte, efter dr. Kleinpaul givne forklaring af det latinske navns oprindelse rigtig, så er altså vort danske ord 
"kat" ikke andet end en afkortet grask præposition (gr. kata o: nedad, henal, med hensyn til o. l.).

Men måske vil en eller anden af årbogernes læsere spörge, af livilke sproglige grunde man slutter, at ord af så hjemlig klang som kal og kat eller lignende stammer fra latinen og ikke or oprindelig nordiske. resp. almengermanske. Sagen er i korthed folgende. Da det germanske grundsprog for umindelige tider siden udgrenede sig fra de ovrige indoevropeiske tungemål, indtridte der $i$ hint en del regelmassige andringer af visse lyd, hvoriblandt oursa den, at et oprindeligt $k$ i begyndelsen af ordene altid blev til $h$, hvorimod de ovrige beholdt deres $k$. Denne forskel har vedvarende holdt sig til vore dage. For så vidt der altså endnu findes tilsvarende ord pä begge sider, vil f. eks. graske $o g$ latinske ord, der begynder med $k$ resp). $c$ regelmassig stå over for oprindelig germanske (danske, tyske, engelske o. s. v.), der begynder med $h$. Si̊ledes har vi f. eks.:

\begin{tabular}{ll}
\multicolumn{1}{c}{ gresk: } & \multicolumn{1}{c}{ latin: } \\
kalamos & calanns \\
kannalis & cannahis \\
keras & cornu \\
kytos & cutis
\end{tabular}

\begin{tabular}{ll}
\hline lansk: & tysk: \\
halm & halm \\
hanf & hamp \\
horn & horn \\
hant & hud
\end{tabular}

I henhold til denne regel kan vi altså slutte, at hvor der jkke foreligger on sådan forskel, men hvor et med $k$ resp. $c$ begyndende ord på den græosk-latinske sido svarer til et dansk (tysk, engelsk o. s. $\nabla$.) ord, der ligeledes begynder med $k$, kan der ikke foreligge en selvstændig udvikling på begge sider, men der må 
have fundet en overforing sted; og det vil da i de fleste tilfælde være givet, at overforingen er grået $\mathrm{i}$ retning med kulturströmmen, i oldtiden altsi̊ fra syd til nord. Men nu har vi jo netop folgende forhold:

\begin{tabular}{llll}
\hline græsk: & lutin: & tysk: & dansik: \\
kavlos & caulis & kohl & kâl \\
kat- & catuss & katze & kut \\
kistê & cistut & kiste & kiste
\end{tabular}

hvorfor altså de anforte danske og tyske betegnelser ikke kan være oprindelig germanske, men ma rære optagne fra latinen. Ganske på samme måde svarer f. eks. græsk-latinsk $p$ til germansk $f$, altsă:

\begin{tabular}{llll}
\multicolumn{1}{c}{ græsk: } & latin: & $\overbrace{\text { tysk: }}$ & dannk: \\
patêr & pater & vater & fader \\
pûs (pod-) & pes (ped-) & fuss & fod \\
pôlos & pullus & fohleu & fole (fol) \\
plektein & plectere & flechten & fletter
\end{tabular}

hvorfor vi af herfra afvigende forhold som:

\begin{tabular}{clll}
\hline græsk: & latin: & tysk: & dansk: \\
peperi & piper & pfefter & peloer \\
- & pondus & pfund & pund
\end{tabular}

allerede på forhånd slutter, at peber og pund ikke er oprindelig germanske ord, men komne til os fra de gamle romere. Og ad lignende reje går slutningerne videre.

Det er dog navulig det senere kristelige Rom, der har givet os en ikke ubetydelig del af vort nuværende ordforråd. 
I forste række gælder dette om et stort antal kirkelige udtryk, der sammen med kristendommen er komne til os. Oprindelig var kristendommen hebraisk, i de forste århundreder var den grask, så blev den latinsk, og endelig kom den også til Danmark. Man oversatte fra det ene sprog til det andet, men derved bibeholdt den græske kirke et antal hebraiske, den romersk-katolske et antal hebraiske og græske, den danske et antal hebraiske, græske og latinske elementer, som ikke oversattes. På denne måde hviler altså den danske kirke så at sige på tre forskellige sproglag. Det hebraiske messias f. eks. benyttes endnu, ihvorvel det på græsk hedder christos og på dansk den salvede. Langt mere naturaliseret er det ligeledes hebraiske påske, der oprindelig hed pesach (forbigang) og betegnede den fest, som juderne fejrede til erindring om deres udfrielse af trældommen $\mathbf{i}$ Egypten og særlig den dertil knyttede omstændighed, at den udsendte dødsengel "gik forbi" israeliternes huse. Hebraisk er desuden jubel, der gennem det latinske iubilum (fryderåb) er kommen af det hebraiske jobel (basun), hrad der forklares ved den antagelse, at jodernes jubeliir (nàdeår) åbnedes med basunlyd; endvidere sabbat (hvile), halleluja (lovet være gud) og flere. Fra det græske stammer hele forfatningen: biskoppen og prcesten, apostelen og munken, klerken og lugmanden sai vel som selve den katolske kirke er græske; de hed oprindelig episkopos (tilsynsmand), presbyteros (den æeldre), apostolos (sendebud), monachos (eneboer), kilerikos (gejstlig), laikos (horende til folket, verdslig), katholikos (almindeligi) og kyriakê (herrens hus). Græske er endvidere 
kristendommens grundbegreber, lige fra profeterne, bibelen og evangeliet til dogmerne, de ortodokse og selve djurelen; prophêtês hedder forkynder, billion bog, evaggelion ( $g g$ udt. ng) glædesbudskab, dogma læresætning, orthodocos den rettænkende og diabolos bagtalersk. Og desuden


tighed), og der læses perikoper (gr. perikoph, afsnit) or bedes kyrie sleison (herre, forbarm dig!). Fra latinens herredömme har vi ikke blot pane, provst og pastor tilligemed domkirke, kloster og kapel, men desuden alter, font og kors samt velsignelse, preediken, offer og pine; de pägxidende latinske former og deres oprindelige betydning lyder: papa (fader), propositus (den foresatte), pastor (hyrde), domus (hus), claustrum (indelukke), capella (lille kappe, specielt den hellige Mortens kappe, derpå den helligdom, hvor denne relikvie bevaredes, og endelig overhovedet en lille kirke), altare (offerbord), fons (kilde), cru, (bjælke med tværtræ, hvorpå forbrydere udspiledes; marterpæl), signum (tegn, her ment: korsets tegn), prcediratio (forkyndelse), offertorium (det tilludte, gave) og pona (straf).

Ad samme vej har vi modtaget de fleste af vore ældre videnskabelige kunstudtryk. Fra Grekenland kom videnskaben til Rom og derfra med kirken til os. De græske videnskabelige udtryk bibeholdtes enten uden videre af romerne eller oversattes på latin, og disse latinsk-græske udtryk fandt derefter videre udbredelse gennem den gejstlige stand, i hvis hænder undervisningen udelukkende lå fra begyndelsen af. Filosofi og teologi, historie og geografi, astronomi og matematik, geometri og aritmetik, musik og grammatik er tilsammen af 
græsk oprindelse, medens religion og jura er særlig latinske betegnelser. Græske er endvidere skolen (scholê ॰: egentlig „frilıed for arbejde“, derpå: videnskabelig syslen, og endelig: undervisningssted) og katederet (kathedra э: egentlig dvælen, dernæst: stol, navnlig lænestol), latinske derimod skolemesteren (magister 0 : lærer), tarlen (tabula ○: bræt) lektien (lectio ว: læsning) og ferlen (ferula 0 : vånd, ris). Sproglæren er gennemgatende latinsk med dens ordklasser (classis 0 : afdeling) som substantivum (det selvstændige), adjektivum (det vedföjede), verbum (ordet) 0 . s. v., dens deklination (biijning) med kusus (fald) og numerus (tal), dens konjugation (forbindelse) med aktivum (det handlende) og passivum (det følsomme) o. s. v. Det samme er tilfældet med regnekunsten, hwis fire species (fremtoninger, arter): addition (tilföjelse), subtratition (fradragelse), multiplikation (mangfoldiggïrelse) og division (deling) samt kvadratrod (quadratus 0 : firkantet) og facit (ordret: det gör) er latinske, og blot don vanskeligere kubikrod mä fores tilbage til det græske kybos (tærning). På skrivekunstens område finder vi derimod græske og latinske betegnelser nogenlunde ligelig fordelte: græsk er alfabetet (af navnene på de to forste til vort $a \operatorname{og} b$ svarende græske bogstaver "alpha“ og "beta") og skilletegnene komma (indsnit) og kolon (led) samt parentesen (parenthesis 0 : indsættelse ved siden af); halvt af hver slags er semi-kolon (semi- er latin, svarende til det græske hemi-, og betyder halv-) ; rent latinske er endelig brevet (breve $\mathrm{o}$ : det korte, nemlig skrift) og dets afslutning: punktum (stik, prik) samt seglet (sigillum o: et lille tegn). 
Ligeledes i folge med kristendommen har vi desuden fảet en del tidligere ukendte hverdags -begreber og deres latinske betegnelser. Dette er navnlig tilfældet på bygningsvæenets område. I oldtiden kendte vore forfædre nemlig kun træbygninger. Som det vides, var endogsi de første kirker i Danmark kun bjæelkehuse, og $i$ et manuskript fra begyndelsen af det 12. århundrede hedder det, at hyer og borge endnu den gang liverken havde mure eller tåne, men kun var befæstede ved grave oy pæleværker. IIen efterhånden lærte munkene, der udenlands fra var vante til bekvemmere boliger, også den hjemlige danske befolkning at opfore stenluse. For vor specielle landsdels vedkommende ved vi bl. a., at kirken i Hedeby ved Slesvig ca. 850 opfortes af træ, men 100 ăr senere ombyggedes af sten, og at fruekirken i Flensborg opbyggedes 1284 i omtrent sin nuværencle skikkelse, efter at en tidligere derværende st. Mariæ kirke af træ var forfalden ${ }^{1}$; og endvidere ved vi, at Knud Lavard ca. 1120 opforte de furste fæstningsværker af sten ved Slesvig, samt at der 1321 i Flensborg fandtes stenhuse ved siden af de oprindelige trabygninger. I Steden for de tidligere trævæuge og pæleværker fremstod der săledes efterhånden mure af sten og kalk, thekkede med tegl, forsynede med tairne og porte, ogr ongivende kamre og koeldere - tilhohe latinske betegnelser, der sammen med de fremmede begreher indfortes hos os af de latinskdannede munke; kun ordenes endel-

1) Den sidste trækirke i Danmark nedlurødis rimeligvis 1709 pả fland ved For. 
ser afviger en smule fra de oprindelige, nemlig: murus (mur), calx (kalk), tectus (tækket, bedækket), tegu!a (tegl), turris, i genstandsform turrim eller turrem (tårn), porta (port), camera (kammer) og cellarium (kælder). Men munkene var ikke blot gode bygmestere; de var tillige fortræffelige gartnere og indførte som sådanne adskillige sydlandske vækster, der tilligemed deres latinske narne efterhånden fik borgerret hos os. Blandt disse gennem klosterhaverne indkomne planter kan nipvnes: petersilie og kirsebcer samt fioler, lilier og roser. Selve ordet plante er det latinske planta. Petersilie er det latinske petroselinum efter det græske petroselinon (egentlig: sten-selleri). Kirsebærtræet, på latin cerasus og på græsk kerasos, blev ifølge Plinius i året 72 eller $71 \mathrm{f}$. $\mathrm{Kr}$. af den bekendte rige og overdadige romerske feltherre Lukullus bragt fra byen Kerasos i det lilleasiatiske landskab Pontos til Rom, hvor fra bảde træet og navnet sa senere kom nord på; det hedder på armenisk keras, pa nypersisk og tyrkisk kires. Fiol og lilie er afkortelser af de tilsvarende latinske betegnelser viola og lilium. Rosen skal have sit oprindelige hjem i Centralasien, hvor fra den over Frygien, Trakien, Makedonien, Grækenland og de græske kolonier kom til Italien. Her trivedes den ypperlig og fandt udbredt anvendelse: hos sybaritterne var et lager af rosenblade meget almindeligt, og kejser Nero bortsdslede engang ved et gæstebud alene for over en halv million kroner roser. Fra Italien kom med selve planten dens latinske navn rosa også til os.

Den omtalte kristelig-romerske indflydelse på vort ordforråds berigelse var imidlertid ikke den eneste, der 
gjorde sig gældende i middelalderen. Fra Valdemarernes tid af åbnede sig også en anden betydelig kanal for tilførslen af fremmede elementer, nemlig over Tyskland.

Det var s̊̊ledes fra Tyskland, at vi fik riddervæsenet og med dette adskillige mere eller mindre adelige begreber med samt deres tyske, og særlig da nedertyske (plattyske) benævnelser.

Af begreber med virkelig adelig duft vil jeg nævne den statelige ridder i hans drabelige rustning, den kïnne junker i hans kostbare skarlagensdragt og den kwekke vảbendrager med hans blanke hellebarde samt den wdelbirne frue, den fyrstelige freken og den hociske jomfiru med deres behorige dejlighed og gunst. De stammer alle direkte fra Tyskland; man jævnfore blot de tilsvarende middelnedertyske ord: statelik (ny-hïjtysk: stattlich); ridder (nht: ritter); draplik (nht: trefflich); rustung (nht: rüstung); kö̈̈ne (nltt: külın), alts̊ oprindelig betydende "tapper"; junker o: junk-herr, altsð̊ ung herre; kostbar (nht: kostbar); scharlaken (nht: scharlach), der forøvrigt ved folkeetymologisk omdannelse med tanken på laken (töj) gennem middellatinsk scarlatum skal være kommet af det tyrkiske iskerlet; dracht (nht: tracht); keck (nht: keck), oprindelig queck э: levende, kvik (jf. (quecksilber); drager eller dreger (nht: träger $\mathrm{o}:$ bærer), hvis tilsvarende danske form "drager" altså ikke har noget med at drage (trække), oldnordisk draya, at gïre; blank (nht: blank), hvoraf ougså det franske blanc og det italienske bianco (middellat: blancus) er kommet; hellebarde (nlit: hellebarte). opstået af helmbarte 0 : hjælmøkse, altså en økse til at 
hugge hjælmen igennen med; edelboren (nht: edelgeboren); vruwe eller vrouwe (nht: frau), der oprindelig er det samme som det oldnordiske frøyja 0 : herskerinde (jf. gudinden Freja eller rettere Fröja efter oldn. Froyja): vurstelik eller vorstelik (nht: fürstlich) af vurste, vorste, der egentlig betyder den "forste"; vroiken eller vrouken, nyere nedertysk tröken, der altså er formindskelsesform af vroune og betyder "lille frue" (svarende til nht: fräulein); hövisch (nht: höfisch) af hof, ejeform hoves; junkerowe (nht: jungfrau), behorich (nht: behörig, gehörig); degelik af tillægsformen gedegen (nht: gediegen); gunst for ge-unst (nht: gunst; i oldhöjtysk blot. unst, der er beslægtet med vort hjemlige yndest, af oldn. unna 0 : unde og elske). Enkelte andre af riddertidens begreber og deres betegnelser som turnering, hainish, panser, visir og lanse or oprindelig romanske, men er optagne med middelnedertysk (middelalderligt plattysk) som mellemled; jf. fransk tournni, tysk turnei, turnier; fransk harnais, der iøvrigt skal stamme fra keltisk, gammelhöjtysk harnas (nht: harnisch); italiensk panciera, glht: panzier (nht: panzer); fransk visiere, tysk visir; fransk lance, ital. lancia (begge at lat: lancea), glht. og nht. lanze.

De ovenfor omtalte begreber vil vistnok fornemmelig egne sig til hos de fleste at fremmane mindet om lyse og lykkelige dage i Danmarks historie; men det gode mel har jo og sine såder, og således fulgte da også $i$ hælene på styrkens, artighedens og glansens periode en tid fuld af selvtægt, falskhed og elendighed, hvori vi ligeledes fra Tyskland fik talrige mindre ædle begreber og deres betegnelser som: dristige lykke- 
riddere, balstyrige stratenrovere, hofferdige gokke og ryggeslese fruentimmer foruden forvorpne bedragere, elendige prakkere, jammerlige dogeniyte og gemene ludere. De pagældende nedertyske ord er driist(ich) (nht: dreist), lücke (ht: ge-lücke, nu : glück), balstürich (slem at styre), straatenröver (nht: strassenrïuber), hoverdich (nht: hoffürtig ৩: hochfährtig), geck (nht: geck), rokelos (af roke, ruke 0 : omsorg, hensyntagen; nht: ruchlos), vruwentimmer (nht: frauenzimmer), vorworpen (nlt: verworfen), bedreger (nht: betrieger, betrüger), elendich (nht: elendig) af elende (opr. eli-lende 0 : „værende $i$ andet land“, dernæst: landflygtig, ulykkelig, ussel), pracher (af prachen 0 : tigge; hollandsk pragcher betyder gnier, ågerkarl), jamerlich (nht: jämmerlich), dögenicht (nht: taugenichts), gemen (nht: gemein) og luder (nht: luder), der oprindelig betyder "lokkemad", navnlig af „kød, der er ved at gå $\mathbf{i}$ forrådnelse“.

I endnu större omfang og med varigere eftervirkning end på riddervæsenet satte den nedertyske indflydelse sit stempel på livetikobstaderne. I den senere middelalder bosatte sig nemlig en skare af tyskere overalt i Danmark: allerede i begyndelsen af Valdemar den forstes regering var der f. eks. så mange tyskere i Roskilde, at det der kunde komme til blodige sammensted mellem det danske og tyske borgerlag.

Men navnlig efter at hansestæderne havde bemægtiget sig Nordens handel, indvandrede tyske $\mathbf{k} \propto \mathrm{b}$ $\mathbf{m} \circledast \mathbf{n d} \mathbf{i}$ stadig stigende antal, og medens de erhvervedo sig både besiddelser og embeder, indforte de samtidig talrige navne pá syd fra medbragte genstande og indretninger. Ad denne vej har vi således ikke alene 
fảet krummer og hoker, lis-pund og lod samt sukker og krydder-nellike, men desuden borger og oldermand, rettighed og pligt samt foged og beddel. Krommer og hoker er nemlig de middelnedertyske krämer (af kram, egentlig: handelsbod) og hö̈̈ker, af hvilket også det hollandske heuker og derover det engelske hawker (gadesælger) menes at være kommet. Lis-pund, mntysk lispunt, er sammentrukket af lives-punt 0 : livlandsk (liflandsk) pund, og lod er det mntyske lont (ejeform loodes), der betyder bly (jf. at lodde). Sukker er dog ikke umiddelbart tysk, men kun med tysk som mellemled kommet til os. Allerede i seldgamle tider dyrkede man sukker i Kina og Indien, hvorfra det tilligemed narnet efterbånden nåede længere vestpå: sanskrit carkarâ, prakrit schakkar, persisk schakar, arabisk sukhar, italiensk zuccaro, zucchero; det var først i korstogenes tid, at sukker blev mere almindelig kendt og derefter over Tyskland også kom til Danmark, hvor man tidligere kun havde honning til at sode med. Krydder-kommer af det mntyske krut (urt), i flertal krüder, hvoraf vi også har vort sønderjyske kru'gå (krudgård o: urtegård) og krurene're (krudenerer ə: urtekræmmer); i steden for „kryderi“ siger vi jo ellers i Nordslesvig sædvanlig kevots, der er det tyske gewuirz. Nellike, sj. nelken, er det mntyske negelken (nht: nägelchen), hvilket navn den har fået på grund af ligheden med et lille söm. Borger og oldermand er ordret mntysk borger (nht: bürger) og olderman (nht: ältermann); older er nemlig ved siden af elder höjere grad af mntysk olt (nht: alt $\diamond:$ gammel). Rettighed og pligt er ligeledes de mntyske rechticheit (nht: gerechtigkeit) og plicht (nht: 
ptlicht). Foged er det mntyske voget, der oprindelig stammer fra det latinske (ad-)vocatus (egentlig: den tilkaldte), hvoraf vi senere desuden har fảet advokat (sagfører). Og beddel endelig er det mntyske bödel (nht: büttel; ght: bütel), der kommer af udsagnsordet beeden (nht: bieten) ว: byde; en boddel er altsa en, der udforer et bud (et retsbud).

Hertil kommer endnu den store skare af tyske håndværkere, der den gang som senere strömmede ind til os og oprettede deres forskellige varksteder. $\mathrm{Pa}$ denne måde har vi både fảet bodker (mntysk bödeker af bodik 0: „boddike“, botte), maler (af mntysk malen, der atter er kommet af mal o: punkt, plet og altså betyder at mærke, plette) og gartner (mntysk gardener) samt slagter (mnt. slachter; i tidligere dansk kiotmangaer, hvoraf f.eks. Kobmagergade), garver (af mntysk garwen, oldht. garwen, mht. gerwen, nht. gerben, der atter kommer af gar og altsa betyder "gar machen“) og sj. knuagendrejer (mntysk knokendreeier $\supset$ : bendrejer) og desuden skrceder (mntysk schraader af schraaden o: skære, klippe, der svarer til nht. schroten), skersliber (mntysk schernsliiper ว: saksesliber) og det nu forældede badskuer (omfortolket af tysk bartscherer, fordi man tidligere også kunde fả sig barberet i badestuerne), samt endelig adskillige -magere (mntysk -maker af maken, nht. machen ०: göre) som dugmager (mntysk dook, holl. doek, nht. tuch), buntmager (mnt. bunt 0: broget blev i Tyskland tidligere navnlig brugt om broget pelsværk), toffelmager (nnt. tufjele, pantuffels af ital. pantofola) og klodsmager (mnt. klotze, glotze, gallotze af fransk galoche). Og blandt disse forskellige håndværkere fand- 
tes der mangen en dygtig mester og redelig fikker, men også en hel del fuskere, smölere, lurendreiere og vigtigmagere, der som oftest forsömte deres håndtering for at gå til dobbel i kroen. Mian jævnføre hertil middelnedertysk duchtig (nht: tuichtig), meester (nht: meister; af lat. magister 0 : lærer), redelik (nht: redlich), ficken, (besliegtet med fleck $ว$ : plet), vusken (der sættes i forbindelse med vuust, nht: faust $\curvearrowright$; næve, så at altså vusken, vuustken, skulde betyde „rode med hainden"), lurrendreeier (af lurre o: lögn), wichtich (nlit: wichtig), vorsumen (nht: versïumen), hanteeren (af fransk hanter ๑: besøge ofte, omgas med), dobbel eller dobbelspol (af lat. duplum $ว$ : det dobbelte; lat. duplo ludere 0 : spille om en stadig fordoblet indsats) og krooch eller kruuch (nyht: krug). Men med handværkeren følger jo også i reglen hans værktöj. Af de talrige indførte tyskdøbte redskaber (mntysk ree(de)schap) skal her blot anfores snedkerens nothevl (mntysk naat, nht. nath ๑: en sïm) og lockbetel (mntysk lok, nht. loch o: hul), skomagerens spandrem (mntysk spannreeme, nht. spannriemen o: spænderem), og plok-syl (mntysk plok, nht. pflock o: kort pind) samt skræderens persejern (mntysk persen, nht. pressen o: presse, trykke), bodkerens krydsholt, (mntysk kruze, nht. kreuz o: kors) og den nordslesvigske murers kell' (tysk kelle o: bred ske, navnlig murske).

Vi står hermed ved slutningen af middelalderen og går derfor nu over til ligeledes kort at betragte en del af det fremmede sprogstof, der i nyere tid har forget vort ordforråd. Det kunde jo derved synes at falde naturligst på lignende måde som hidtil at opsøge 
de vigtigste af de os berorende kulturkanaler for at se, hrilke nye begreber med dertil knyttede betegnelser disse har bragt os. Men en fortsat vandring ad denne vej turde både blive temmelig vanskelig og vidtloftig; thi de forskellige strömninger, der siden Amerikas og det heliocentriske solsystems opdagelse samt krudtets og bogtrykkerkunstens opfindelse har sat os i stadig roksende materiel og andelig forbindelse med den ovrige verden, er alt for talrige og i hverandre for rrenede til at kunne valges som holdepladser for så jevne og forholdsvis korte betragtninger som vore. Vi vil derfor soge at anstille de nærmestfolgende iayttagelser fra enkelte, ganske vist mere vilkarlig valgte, men ikke des mindre forhâbentlig hensigtsmassige udsigtspunkter.

Lad os forst gå ud prå at freste vort blik ved en del af de mest almindelige tilfælde.

Vi har der på den ene side et antal forskellige indretninger, både af offentlig og privat natur, der tilligemed deres benævnelser er komne til os fra udlandet.

På det offentlige livs område er det navnlig Fıankrig og Tyskland, vi har faet en del nyere institutioner fra. Af hof- og statsembedsmændene er $b a$ ronen, prusidenten, ministeren, intendanten, rendanten, sekretceren og gendarmen franske, medens greven, gesanclten, en mængde råder, som hofråden, statsråden, gehejmeråden, landråden og forstrîden, sant jagermesteren, kammerjugeren og natvcegteron er tyske. Selv på landdelingens område har vi et par indvandrere, nemlig det tyske amt og den franske kommune (fr. commune udt. 
kommyn; i sønderjysk ligeledes kommyn'). Men navnlig iblandt militceret (fransk militaire af lat. militaris 0 : horende til krigen) vrimler det af begge slags fremmede: fransk er selve armeen, både infanteriet, kaculeriet og artilleriet med deres regimenter, kompagnier (og eskadroner og de fleste officerer fra generalen ned til sekondlöjtnanten samt sergenten, soldaten, musketten og kanonen (det sidste dog måske italiensk); tysk er derimod staben, obersten og ritmesteren, vagtmesteren og gefirejderen ( $\odot$ : den, der er fri for at stå shilduagt) samt yeveret og pikkelhatten. Mere særskilt haves fra Italien marketenderen og provianten (italiensk mercatante $\mathrm{o}$ : handler, og provianda af lat. providenda $\mathrm{\jmath}$ : det, som der må sorges for), samt fra Cngarn husaren, der betyder den tyvende (af ungarsk husz ๖: 20). Tnder den ungarske konge Matthias ('orvinus (1458-1490) vedtoges det nemlig, at hver tyvende. mand skulde vare soldat, og de således udskrevne tropper kaldtes derfor husurer; men senere var det kun rytterne, der bibeholdt narnet, som derpa i denne betydning tilligemed ungarernes snorede frakker efterhänden gik over i de fleste evropæiske hære. Af de til samfardselen tjenende offentlige indretninger endelig er bl. a. tunnel og vagon af engelsk, kupé og post af fransk og onnibus af latinsk oprindelse; omnibus er dativ pluralis af det latinske omnis (enhver) og hedder altsá ,for alle".

Pa det private livs omrăle har vi ligeledes talrige indvandrere. Det nyere forretningsliv or for en stor del romansk, og da navnlig fransk: således fabrikken (fransk fabrique af latinsk fabrica 0: værksted, der 
atter er en afledning af faber o: en, der arbejder $\mathrm{i}$ hårdt materiel: en snedker eller smed) og bureaust. eller kontoret (fransk comptoir) med chefen og kommis'en, endvidere indretninger som patent, reklame, rabat $0 . \mathrm{s} . \mathrm{v}$. samt målene meter, liter, gram og ar; meter, fr. mètre er oprindelig det græske metron, der betyder "mål”, gram, fr. gramme, det græske gramma $\left(={ }_{1}^{1}, 3\right.$ draclime eller 2 oboler), ar, fr. are, det latinske area 0 : fri plads, flade (jf. areal, arena). Af italiensk oprindelse er firmaet og grossereren, af engelsk derimod intervieucet og st, pjken og af tysk gesjuften, litzenbroderen og „e boss'"; litzenbroderen (nt. litzenbroder, ht. litzenbruder) har sit narn af de lisser eller snore, lian er forsynet med til at bære rejsetijj etc. i, og det sonderjyske boss' (vandrende håndværkssvend) er en overforelse af det tyske bursch, der egentlig betyder student og derefter lærling, svend og ungt menneske overhovedet. Foreningsor sportslivet er sierlig engelsk: man trenke f. eks. já klub, odd-fellow og good-templar samt \& ports-ting som cricket, lawn-tennis, match, start o. s. v.; regatta er derimod italiensk og stammer specielt fra Venedig, hvor der tidligere foranstaltedes årlige kaproninger for at göre ungdommen sodygtig (ital. regata, remigata o: roning). Selskabslivet er igen for en stor del fransk, f. eks. visit, soiré, konversation og dans m. m. fl. Af dansene stammer kotillonen, franciesen og lancieren (egentlig les lancier's o: lansedragerne) ligeledes fra Frankrig, mazurkaen og polonisen derimod fra Polen, valsen fra Tyskland og polkaen fra Bolmmen, hvor den 1830 blev opfunden af en landsbypige Anna Slezak; det tjekkiske ord pulka betyder si meget som "halvskridt". Kort- 
spillet er ligeledes kommet syd fra. L'hombre er en spansk opfindelse, men spillet hedder i Spanien tresillo (trespil, jf. vort trekort), og det spanske hombre betyder "mand" o: spilleren; i Frankrig overforte man den sidste betegnelse på selve spillet og satte det franske bestemte kendeord foran, så der opstod l'hombre. Fra Spanien har vi endvidere trumf (sp. triumfo af det latinske triumpllus $\supset$ : sejerstog) og matador (draberen, lat. mactatos), fra Italien solo (alene), fra Frankrig bet (fr. bête o: dyr, fie, fahoved), fra England whist, der er det samme som vort hys! eller tys!, da spillet kræver opmærksomhed oy derfor tavshed, og fra Tyskland "bedste beskup" og formodentlig sjaus; beskup kommer nemlig af nedertysk beschuppen (bedrage), og sjavs skal rare en forvanskning af schafskopf. Af betegnelser pa de $\mathrm{i}$ vort nyer'e samfundsliv mere eller mindre fremtrædende menneskelige egenskaber har vi endelig fảet ord som nobel, galant og elegant fra Frankrig, men gavtyv og svindler, gevalt, underdanig og sjofel fra Tyskland; ordet sjofel er jodetysk og kommer af det hebraiske schifèt, der betyder sá meget som ussel og Iurvet.

Men foruden de næunte og en mangde andre institutioner har vi som bekendt faet talrige frembrinyelser, både kultur- og natur-produkter, fra fremmede lande.

Blandt de pågreldende kulturfrembringelser næevner jeg forst et par huslige indretninger og redskaber. Veranda skal være et sanskritord, som portugiserne har bragt med fra Ostindien, og som betyder en "tildækket hal" (portugisisk varanda), balkon er 
italiensk, og bassin er fransk. Franske er desuden vore fleste nyere mobler (fr. meuble af lat. mobilis $\partial$ : bevigelig), som chaiselong (fr. chaise longue 0 : langstol), buffet, kommode (fr. commode o: bekvem), necessirfe (fr. nécessaire 0 : nodvendig), servante (egentlig: tjenestepige) o. s. v.; fortepiano eller pianoforte er derimod italiensk (forte 0 : stærkt og piano 0 : sagte) og sofa er ligefrem tyrkisk: i Tyrkiet kalder man nemliy husenes forhal, der pa de tre sider er forsynet med löjbienke, soła, ng derfra stammer den hos os bekendte betydning af ordet. Af kokkentöjet er bl. a. platmenage og vort sonclerjyske boddel af fransk oprindelse (fr. bouteille .): flaske). Interessantere er imidlertid tallerkenen. Den stammer fra fransk tailloir eller italiensk tagliere (begge af middellatinsk taleare 0 : at skære af), der nu betyder "hakkebret", men tidligere var et skirebrat, som kodet bares ind og skares for på. Det var oprindelig den eneste tallerken, der stod pä bordet, og de spisende havde $\mathrm{i}$ det höjeste hver et stykke brod til at læuge deres kod på. Da det sả senere blev skik, at liver enkelt ved bordet fik en særskilt del til at spise af, overførte man skærebriettets navn på disse personlige smäfade. I Tyskland tik orlet formerne teller og tellerchen, nedertysk tellerken (lille tailloir), hvoraf vi sả bảde har rigsmålets tallerken og sonderjysk tel'ler og ler'ken. Af disse vore tre forskellige benæernelser er altsă tel'ler et oprindelig romansk ord, tallerken det samme romanske ord foroget med en tysk formindskelsesendelse og ler"ken ikke andet end summen af en fransk og en nedertysk navneordsendelse. Tager vi dernæst et par af de nyere vogne, så finder vi, at 
yigen er kommen fra England, kalechen over Frankrig fra Bølimen (fransk caliche, bøhmisk kolesa) og droshen fra Rusland (russisk droschki). Af beklædningsgenstandene er vor jakke (sonderjysk jak) den franske jaque, slips er flertal af det engelske slip, der betyder lap, strimmel og „kobbelbånd på jagthunde“, og shawl (udt. sjal) er den engelske skrivemåde for det tyrkiske schal. Paraplyen og parasollen har vi fiet fra Frankrig. De er begge to ikke så overmåde gamle: paraplyen er forst for 100 år siden fremstået af parasollen, efter at denne ca. 1770 var kommen til Frankrig fra Italien. Italienerne har for begge disse redskaber ordet ombrello ๑: "hvad der giver skygge". Vore töjsorter er temmelig brogede, også med lensyn til nationaliteten: atlask er i det 15. århundrede kommet til Evropa fra Morgenlandet, hror det arabiske atlus betyder "glat silketörklæde", taft er det italienske taffetì, der skal være af persisk oprindelse, krep er det franske cripe, der stammer fra det latinske crispus (krus), stirting er engelsk og betyder egentlig „töj til skjorter" (eng. shirt 0 : skjorte), bommesi er det tyske baumseide o. s. v. $\mathrm{Og}$ i det mindste lige så brogede er vore nyere levnedsog nydelsesmidler: vor budding er den engelske pudding, der oprindelig ikke er en melspise, men en kødret (polse: jf. fransk boudin), og vor sky i betydning af "storknet kraftsuppe" den franske jus (udtalt sjy; latinsk jus o: suppe). Vor lineonade kommer af det italienske limon, der betyder „citron“, og er altsă egentlig "citronvand", så at f. eks. hindbcerlimonade sproglig betragtet er ligefren vås; sjokoladen (chokolade), som spanierne allerede 1519 fandt $i$ brug hos 
meksikanerne, er en sammensætning af det meksikanske choko (kakao) og latl (vand); vor cigar, spansk cigarro, skal både med hensyn til navn og opfindelse stamme fra øen Kuba, hvis oprindelige beboere ved Amerikas opdagelse fandtes i besiddelse af både tilbiijelighed og erne til at ryge sammenrullede tobaksblade; og punchen endelig er i slutningen af det 18 . århundrede af englienderne bleven bragt til Evropa fra Ostindien, hvor ordet, oprindelig sanskrit pantscha, betyder "fem" og betegner, at drikken bestaar af fem elementer: sukker, arak, te, vand oy citronsaft; ror specielle nationaldrik "kaffepuns" ma vi som follge deraf jo egentlig frakende retten til navnet punch, da den forskriftsmæssig kun indeholder fire elementer.

$P a ̊$ lignende måle har vi fiet et ikke ubetydelignt antal naturprodukter, navnlig af planterigot. Blandt de vejrvante fremmede planter vil jeg her blot nievne kartoflen og agurken. Kurtoten stammer som bekendt fira Amerika, lworfra den i sidste halvdel af 16. ărhundrede bragtes til Erropa. I begyndelsen kaldtes den almindelig batate pă grund af dens lighed med denne allerede noget tidligere indforte knoldveckst: i Norge og Sverige hedder den stadig potet resp. potatis (flertal potüter), og her i Nordslesvig er navnet botede for kartofler endnu $\mathrm{i}$ erindring hos enkelte gamle. Nen i det nordlige Italien fandt man, at den narnlig lignede treflen, en underjordisk jordsvamp, hvis italienshe navn er turtufo, tartufolo, og man overforte da dette på kartoflen. Fra Italien vandrede derp̊ navnet tartoffel mod nord, hvor det senere - af grunde, hris nærmere betragtning mere ligger inden for et af 
de folgende afsnits rammer - $i$ almindelighed forandredes til kartoffel og specielt her hos os til kantof'el. Agurken derimod har vi i lobet af det 17. arhundrede fảet fra Polen, hvor den hedder ogoreh, et ord, der kan fores tillbage til det graske agyourion (udt. anrrgurion) o: vandmelon. Blandt de ikke akklimatiserede naturfrembringelser, der i fremtræadende grad har vundet indpas hos os i den nyere tid, turde nogle af de interessanteste være sago og majs, kaffe ogr te samt tobak og kakao. Sugo, der er navnet pă den spiselige marv af en vis slags palmer, har vi faet fra papuaerne, i hvis sproy ordet sagu betyder sü meget som "brod". Majs derimod er af amerikansk oprindelse; dens andet navn "tyrkisk hvede" berettiger ikke til den slutning, at vi har faet den over Tyrkiet, men er kun en hentydning til, at den er kommen fra fjarne lande. Badde kaffe og to har hjemme i Orienten. Kaffen har vistnuk længe været brugt som nydelsesniddel $\mathbf{i}$ sin hjemstavn, det tropiske Østafriki, men først $i$ den nyere tid er den bleven bekendt $i$ videre krese: $i$ begyndelsen af det 15 . århundrede kom den til Arabien, $153 \pm$ til Konstantinopel og i lobet af det 17. århundrede til Vestevropa. Den hedder pa arabisk kalva, pa tyrkisk kahve. Om landskabet Kaffu i Ostafrika, hvis indre bedækkes af store kaffetraskove, oprindelig har givet planten sit navn eller omvendt fảet det af denne, er et af de spørgsmål, der ikke besvares helt ens af de lærde. Teen stammer fra Kina, hvor brugen af tevand er meget gammel; allerede ved slutningen af det 8 , århundrede var der f. eks. lagt skat paa teen i Kina. Men forst i lobet 
af det 17. arhundrede kom den til Evropa, hror den despa langsomt vandt udbredelse. Dens almindelige kinesiske navn er tscha, men i Fukian, en meget terigr provins i den sydostlige del af landet, lyder det tire, og det er dette narn, rort erropreiske te er en afleegger af. Tohak ogr kakao har derimod hjemme $\mathrm{i}$ Amerika. Da Kolumbus 1492 var landet pí Guanahani, så han de indfodte putte cylinderformede, med et majshlad omviklede ruller af toba'ssblade $\mathrm{i}$ munden on lave tabako o: "rog" for at holde moskitoerne lorte fra ansigtet. Pa Haiti rog de indfodte tobakken ladide i sammenrullede blade og skaren af lange ror, $o g$ et sadant ror - efter andre den omtalte majsbladrulle - skal dèr hos de rilde have hedt tabako; atter anilre mener, at tohakken har fuet sit navn af oen Tobago eller også provinsen Tabasko i Mellemamerika. Helt sikker er altsi̊ kun navnets indianske oprindelse i almindelighed. Selve tobaksrygninyskinsten importeredes allerede ved midten af det 16 . anrhundrede af spanske matroser fra Vestindien til Spanien og 1586 af engelske kolonister fra Virginia til England; 169.2 bragtes den af engelske og hollandske tropper til Tyskland, hvorefter den, navnligr ved 30arskrigen. snart bredte sig videre. Brugen af tobak som skrä og snus er evropaiske opfindelser. At skri er det nedertyske schrooen, mnt. schmoden o: skære, tygrge, male i mindre stykker (jf. at skra korn 0 : grutte), oy snus hænger sammen med (nt.) snut ว: snude. Kakao endelig er et meksikansk ord. Da spanierne 1519 kom til Mleksiko, forefandt de kakaobönnen i almindelig brug hos beboerne, og det ikke alene som nydel- 
ses-, men også som betalingsmiddel; 1000 bönner havde den gang som mont en værdi af omtrent halvtredje kroner. Endnu den dag i dag skal beboerne af republikken Costa Rica benytte kakaobönner som skillemont.

Ved siden af den sâledes omtalte nere almindelige tilvalist mả vi imidlertid ogsă nævne et par $s \mathfrak{r}$ egne grupper af fremmede elementer, der ligeledes i nyere tid har beriget vort ordforråd.

En sådan særegen gruppe dannes bl. a. af et antal ord, der stammer fra udonlandske e gennavne, ox da hovedsagelig navne på steder (byer og lands med folk) og visse personer.

Som bekendt har vor ogsa i udlandet yndede ailboryer og vore fortrinlige verdensberömte grióstenere fact deres navne efter to af vore hjemlige byer; og pa tilsvarende måde er flere af vore indforte produkter og indretninger opkaldte efter deres udenlandske hjemstarn. Saledes er ordet tivoli, i nyere tider navnet pä manye forlystelsessteder (som i Flensbory, Haderslev, Kobenhavn o. s. v.) kommet af byen Tivoli i Mellemitalien (det gamle Tibur), der er berömt for sine yndige omgivelser, et 60 fod hïjt vandfald og maleriske ruiner. Ligeledes fra Italien, nemlig fra byen I'istoja i provinsen Florens, har vi fảet pistolen, medens et andet mordinstrument, bajonetten, or kommet fra fastningen Bayonne i Frankrig. Formodentlig er det også militær fra det sidstnævnte land, der har bragt os den væmmelige sygdom, man efter dens bringere kalder fransoser. En bado fredeligere og mere tiltalende gave har vi derimod fiot fra Bølmen, nem- 
ljy daleren, tysk thaler, der forste gang blev montet 1 o18 i den belmmiske by Joachimsthal, hvorefter den oprindelig kaldtes joachimsthaler og senere afkortet thrler, plattysk og sonderjysk dåler, rigsdansk daler. Der har eksisteret flere slays dalere, men den eneste, vi nu har tilbage hos os, er den velkendte pröjser, der selvfolgelig har fåtet sit navn efter landet, den er prieget $i$, ligesom en anden, mindre vardifuld mont, den for henimod 30 ar siden afskalfed hamborger (en hamborre) havde fonet sit efter hyen, den kom fra. En ham'borre hedder hos os jo desuden on dans, der rigtignok stammer fra Bohmen, men vistnok er nået til os over Hamborg. Giar vi dernæst over til klade-, fode- oy drikkevarernes omrăde, så finder vi f. eks., at ligesom nanking, musselin og damash i sin tid har fitet deres: respektive navne af byerne Nanking i Kina. Mossul ved Tigrisfloden og Damaskius i Syrien, säledes er nussa korduan (et fint, narret læder af gedeskind), tigl og manchester opkaldte efter de steder, hvor de furst or blevne fabrikerede, nemlig Korilova i Spanien, Tulle (udt: tyl) i Frankrig on Manchester i England. At vi har sardiner fra Sardinien og horender (korinter) fra Korinth, ved jo alle, men miske er det mindre bekendt, at allerede korsfarerne medbragte skulntter fra Askulon i Syrien. Af nyere oprindelse er derimod atter appelsinen samt vort sonderjyske navn pă boghveden, tarre. Sina er det samme som Kina. appelsin eller abildsin altsă sina-uble eller kina-ceble. I det 16. arhundrede bragtes de forste appelsiner af portugisiskr. sofarere fra Kina til Portugal, hvorfra de să udbredte sig langs med Middelhavets kyster til langt ind i Vest- 
asien: $i$ disse lande dobtes de efter overbringerne, nemlig italiensk portugalli, græsk portogalia og selv kurdisk portoghal. Hos os har de derimod som sagt faet navn efter lijemlandet: da lıamborgerne for omtrent et par hundrede år siden modtog den forste sending osterlandske „æbler", kaldte de dem appelsinen, "ㅆ der fra kom navnet med frugten også til os. Borliveden stammer formentlig fra sibirien og Mongolict, hvorfra den er fort imod vest af tatarerne eller (som alle mulamedanere $i$ sin tid hed) saracenerne. I $\mathbf{E v}$ ropa kendte man den ikke $i$ oldtiden. Man mener, at den forst er kommen til Middelhavet og der fra lıar udbredt sig vest og nord på. I Italien og Frankrix laar den faet sit narn efter saracen'ine, idet den lia italiensk hedder grano saraceno og la fransk ble sar'asin (sarasenisk korn). I de nordlige egno af Erropa naveves den forste gang 1436 i et register fra antut (radobusch i Meklenborg, og her i landet bler den indfort $\mathrm{i}$ lohet af det 16. århundrede. I Tyskland or de fleste egne af Danmark kaldte man den i betragtning af karnens lighed med bog ( $\mathrm{x}$ : frugten af boge. træet) buchweizen, bookwe(i)ten, henholdsvis boglıvede : men andre steder, som i Polen og Finland samt pa Langeland og $\mathrm{i}$ dele af Nordslesvig, dolites den efter de næunte tatarer, idet den pă polsk hedder tatarka, på finsk tattari, på langelandsk tadder og på sonderjysk tarre. Af vor nyere tids drikkevarer endeligr stammer champagne fra landskabet Champagne i Frankrig, sherry eller xeres-vin kommer fra byen Xeres i Sydspanien, portvin forsendes fra Forto eller Oporto i Portugal, kognak destilleres $\mathrm{i}$ den franske by Cognak, 
og hror man har brygget den forste bajer, behover vist næppe at tilföjes.

På grænsen mellem de ord, der stammer fra stedlige egennavne, og dem, der er komne af navne pà visse til deres oprindelige fremkomst knyttede personer, står ordet landauer, for si̊ vidt som det næppe er afgjort, om den forste af den slags vogne er bleven fabrikeret i byen Landau i Bajern, eller om den er opfunden af englænderen Landow. Derimod vides det mere sikkert, at en anden vogn, den nærmest af franske romaner bekendte fiaker, er opkaldt efter den hellige Fincrius, hvis billede var anliragt over indkørslen til et hus i Rue St. Martin i Paris, "Hôtel de Saint Fiacre", hvori en ris hr. Sauvage $\mathrm{i}$ året 1640 oprettede den forste hyrevognsstation; den hellige Fiacrius, en irsk munk fra det 6. årlundrede, skal ellers være gartnernes særlige skytspatron. Ligeledes fra Frankrig stammer et tredje "befordringsmiddel", nemlig guillotinen, der er opfunden af den franske læge Joseph Ignace Guillotin (1738 -1814). Et med den sidstnærnte forestilling delvis besliegtet begreb, den såkaldte lynch-justits, har vi derimod fået fra det engelske sprogområde; at lynche er nemlig: egenhændig at afstraffe virkelige eller formentlige forbrydere ligesom den amerikanske farner Joln Lynch, der henimod slutningen af det 16 . arrhundrede, da talrige flygtede slaver og forbrydere huserede i Nordkarolina, af den derværende befolkning fik uindskrænket fuldmagt băde som lovgiver og dommer og derefter plejede selv at befordre de pågrehne syndere over $\mathbf{i}$ den anden verden - efter andre deri- 
mod ligesom den irske borgmester Lynch, der 1495 uden videre selv gik hen og hængte sin egen sön, da denne havde begået et mord og skarpretteren viryrede sig ved at fuldbyrde straffen. Engelsk er endvidere det mere moderne ord at boykntte, der betyder at behandle en mand pa lignende måde, som irlenderne 1880 behandlede den for sin strenghed forharlte engelske forvalter James Boycott, idet de systematisk afspærrede ham fra alt samkvem med omverdenen ved hverken at ville arbojde for ham, kobe af ham eller sælge det nødvendigste til ham. Blandt de mere fredelige opfindelser nævner jeg galvanismen, draguerrotypien oy silhmetten, hroraf de to forste er opkaldte efter deres opfindere, den italienske professor Luigi Galcrni (1790) og den franske maler Duguerve (1822), medens silhouetten af en anden grund har fået sit navn efter en $i$ sin tid bekendt tinansminister i Frankrig, Etienne de Silhouette: denne var nemlig på grund af forskellige forholdsregler, han ca. 1757 havde truftet, bleven så almindelig forhadt, at man allevegne sogte at göre ham latterlig og navnlig kaldte alt, hvad der så usselt og fattigt ud, à la Sillouette; pả denne måde tillagde man også specielt de dengang i Paris moderne skyggerids-udklip dette hans narn for derved at stemple dem som dårlige gengivelser. Af beklædningsgenstandene hidrorer batisten ligeledes fra en franskmand, en tidligere væver Baptist, medens havelokken er opkaldt efter en engelsk general, Sir Henry Havelock (17951857). Blandt blomsterne skal fremhæves et par så bekendte som fuchsia og georgine, af hvilke den forstnæunte er opkaldt efter den tyske botaniker Leonhard Fuchs 
(1501-1566) og den anden efter en russisk professor ved navn Georgi. Og af de på maven virkende midler endelig kan nævnes nikotin og grog. Nikotinen, et som bekendt $i$ tobaksbladet indeholdt stof, har på anden hånd fået sit navn efter franskmanden Jean Nicot, der 1560 som gesandt ved hoffet $\mathrm{i}$ Lissabon sendte tobaksfrø til Frankrig; til ære for ham kaldte nemlig senere Linné tobaksplanten nicotiana, og heraf dannedes så atter betegnelsen for det omtalte giftige alkaloid. Mindre lærd, men til gengæld morsommere er groggens oprindelseshistorie. I forrige århundrede levede i England en admiral Vernon, som plejede at gå med en frakke af en slags kamelgarnstöj, der på engelsk hedder grogram. Denne frakke gav anledning til, at admiralen hos sine undergivne fik øgenavnet Grog (the old Grog), og da han så 1740 gav ordre til, at skibsbesætningerne ikke som bidtil måtte få ublandet rum, men kun rum med varmt vand $\mathbf{i}$, så døbte de krænkede søfolk den påbudte blandingsdrik efter dens ophav og kaldte den grog.

En anden særegen Gruppe har derimod atter sin rod i de klassiske sprog, idet nemlig hovedsagelig en stor del navne på opdagelser og opfindelser fra nyere og nyeste tid er dannede af græske og latinske ordstammer.

Fra det $\mathrm{græske}$ oldsprog stammer således på fysikkens område foruden selve den altbeherskende elektricitet (af êlektron 0 : rav) bl. a. en hel del sammensætninger med -meter, -skop, -grat og -fon, der selv er afkortelser resp. afledninger af de græske ord metron (måler), skopein (at skue), graphein (at skrive) og 
phônê (stemme, lyd). Af sådanne sammensætninger kan nævnes: termometer (varmemåler) af therma (varme), borometer (lufttrykmåler) af baras (tyngde) og arcometer (redskab til at finde vædskers vægtfylde) af araios (tynd); endvidere mikroskop (forstörrelsesglas) af mikros (lille), altså egentlig "lilleseer", teleskop (större kikkert med indlagt spejl) af têle (i det fjærne, langt borte) og stereoskop (instrument, gennem hvilket to forskellige billeder af samme genstand ses som et virkeligt legeme) af stereos (stiv, fast); desuden telegraf (fjærnskriver) af det omtalte têle (fjærnt), fonograf (lydskriver) af det ligeledes omtalte phône (lyd, stemme) og fotograf (lystegner) af phôs, ejeform phôtos, (et lys); og endelig Graham Bells telefon, D. E. Hughes mikrofon og den iforfjor af den danske ingenior V. Poulsın opfundne telegrafon, der jo alle uden videre lader sig forklare af de forhen anforte betydninger. $\mathrm{Pa}$ kemiens omri̊de har vi bl. a. fosfor af det omtalte phis (lys) og phoreus (bærer), klor af chloros (gulgrön) og dynamit af dynamis (kraft). Særlig græsk er dog den nyere lægevidenskab, således f. eks. ikke alene stetoskopet og de antiseptiske midler, men også trikiner og bakterier, difteritis og diarré samt tyfus og vistnok kolera: stetoskopet, lægernes lytteror, er egentlig en "brystseer", eftersom ordet er dannet af stêthos (bryst) oy skiopein (at skue); antiseptisk kommer af anti (imod) on sêpesthai (at gå i forrådnelse), trikin af trichinos (af hår, tynd som et hår) og bakterie af baktêria (stav); difteritis består af stammen $\mathrm{i}$ ordet diphthera (hud) og den ejendommelige, særlig medicinske afledningsstavelse -itis, der anțder en betændelse, hvad der jo svarer 
til, at den næunte sygdom er en slimhindebetændelse; diarré er en substantivering af verhet diarrhein (at flyde igennem, være læk) og tyfus en overforing af typhos (røg; dernæst: bedøvelse, vildelse), medens kolera efter nogle skal være dannet af det græske cholê (galde), efter andre derimod af det hebraiske chole-ra (den slemme syge).

Blandt de fra la tin en hentede nyere betegnelser har vi i forste række et antal navne pi naturkræfter som f. eks. inerti, gravitation, centrifugal- og centripetalkraft, samt affinitet, kohæsion, adhæsion o. s. v. Inerti (eller vis inertice o: dorskhedskraft), d. v. s. legemernes mangel pi evne til af sig selv at forandre deres hvile- eller bevægelsestilstand, er en afkortelse af det latinske inertia (uvirksomhed, ulyst til arbejde); gracitation, den af Newton efterviste almindelige tiltrækning, som legemer udorer pa hverandre i forhold til deres nasser og $\mathrm{i}$ omvendt forhold til afstandenes kvadrater, kommer af lat. gravitas (tyngde); centrifugal og centripetal er dannede af centrum, ejeform centri, (midtpunkt) og henholdsvis fugere (flygte) og petere (søge, stræbe hen til), så at altså de dermed botegnede kræfter betyder ,midtpunktflyende" og "midtpunktsøgende" kraft; afjinitet, d. e. uligeartede stoffers tilböjelighed til at forene sig med hverandre. er latinens affinitas (svogerskab), og kohcesion og adhrsion er dannede af coherere (hænge sammen) og adhurere (hcenge ved), hvad der jo svarer til, at kohæsion er den kraft, der holder ensartede masser sammen, medens adhæsion er den, der bringer uensartede legemer til at holde fast ved hinanden. Men også navnene på 
en del maskiner og apparater er hentede fra latinen, som f. eks. decimalvægt og centesimalrægt, lokomobil oy lokomotiv, velociped og turbine samt det på grund af sin umulighed endnu ikke opfundne perpetuun mobile. Decimal og centesimal er dannede af decimus (den tiende) og centesimus (den hundrede) og betegner, at den ene arm på de næunte vægtskảler kun er $1 / 10$ resp. 1/100 så lang som den anden. Lokomobil og lokomotiv er bentede fra locus (sted), ablativ loco (fra stedet), og henholdsvis mobilis (bevægelig) og moticus (horende til bevægelsen, bevægende); velociped er tagen af velox, ablativ veloci, (hurtig) og pes, ablativ pede, (foll), og celoci pede er sàledes ordret "med rap fod", medens turbine, af turbo (hvirvel), ablativ turbine med trykket pá forste stavelse, egentlig hedder „i hvirvel"“; ,med hvirvelvind"; perpetuum mobile endelig er helt uforfalsket latin og betyder „det bestandig bevægelige". Til apparaterne horer desuden et antal med endelsen -tor, der egentlig betegner en handlende person, men her er overfort pa de virkende genstande, f. eks. motor (bevæger) af nocere, tillægsform motus, (bevage), regulator (ordner) af regula (rettesnor), konduktor (leder) af conducere (føre sammen), akkumulator (samler) af accumulare (ophobe), der atter er dannet af cumulus (en höj) o. s. v. Fra andre områder vil jegr til slutning endnu nævne krigskunstens torpedo samt lægekunstens vakcine og skrofulose, der tilfældigvis alle tre or hentede fra dyreriget; torpedo er nemlig det latinske navn pd en fisk, den elektriske rokke, og betyder oprindelig "stivhed", medens vak- 
cine, den bekendte koppematerie, er dannet af vacca (ko) og skrofler kommer af scrofn (so).

Ved nu blot at kaste et flygtigt blik tillsage på alle de hidtil fremdragne eksempler og samtidig at tage i betragtning, at disse jo kun står som enkelte repræsentanter for et större hele, vil vistnok enhver få en folelse af, at det ikke er noget så helt ubetydeligt antal af fremmede elementer, vort ordstof i tidernes lob ad forskellige reje er blevet forøget med.

Men denne overordentlige forøgelse med udenlandsk sproggods er selvfølgelig ikke ejendommelig for det danske tungemål alene. Det tyske sprog f. eks. har foruden de fleste fremmede ord, ri kender hos os, ogsả optaget andre, for hvilke vi i dansk som oftest har mere hjemlige betegnelser: sa helt almindelige tyske ord som butter (smör), fenster (vindu), insel (o), pferd (hest) o. s. v. er således ligefrem tagne af de tilsvarende latinske butyrum (der ifolge Plinius skal vare hentet fra Skyterne), fenestra, insula og paraverelus; andre er komne fra andre sprog, som arzt (læge) af græsk archiatir (overlæge; gennem formerne archiater, arziater, arzat, arzet til arzt), gauner (bedrager; gennem jauner eller joner) af hebraisk jin i' (snyde), schöps (en bede) af tjekkisk skopec (sj. gæld'evæ ə: gildet væder), tasse (kop) gennem fransk tasse af arabisk, turnen (at drive legemsøvelser, gymnasticere), som tyskernes "turnvater" Jahn og andre har ment var „ein deutscher urlaut", af fransk tourner (dreje sig, vende sig) o. s. v. Omvendt er ogsâ germanske ord gåede over i andre, f. eks. romanske sprog. Således er de 
almen-germanske ord gans (hos os nu gås) og brok (oldhöjtysk bruoch, angelsaksisk brôc, oldnordisk brik, ældre dansk brog o: bukser) allerede af de gamle romere blevne overtagne under formerne ganta og braca: vi ved nemlig, at store skarer af germanske gæs $i$ oldtiden blev drevne til Rom og dèr i modsætning til de indfodte romerske "anseres" kaldtes gantae (deraf spansk gansos); og vi ved desuden, at medens vort nu almindelige klædningsstykke vesten $\mathrm{i}$ senere tid er kommet fra syd til nord (gennem fransk reste af lat. vestic э: klædning), er omvendt brogen (bukserne) allerede i oldtiden vandret fra nord mod syd, hvor det af den tilsvarende latinske form braca dannede tillægsord bracatus ikke alene betød brog-klædt (buksekladt), men navnlig også „udenlandsk, barbarisk“, og hvor ordet derefter i italiensk er blevet til brache, i fransk til bragues og braies. Af almengermanske ord i fransk har vi desuden bord (rand, skibsside), banc (bænk, sandbanke), cloche (klokke), blanc (hvid, ren), brun (brun), haler (hale op), laper (slikke op, labe) o. s. v. Specielt fra tysk har franskmændene fået et par dỵr som le hamster (hamsteren), le marsouin (marsvinet), l'écrevisse (krebsen) og le crabe (krabten) samt navnlig en del krigerske begreber som lansquenet (landsknæut), landwehr (tysk: landwehr), landsturm (landstorm), bannière (banner), bivouac (t. biwacht, beiwacht) m. fl., og desuden bl. a. loustic (t. lustig) og bigot (overtroisk from, skinhellig), hvilket sidste ord menes at være en ligefrem overforelse af det tyske bi gott (bei gott 0 : ved gud), samt brandevin (t. branntwein), og choucroute (t. sauerkraut). Surkallen tilligemed tyskernes forkxr- 
lighed for denne deres "nationalret" er dog ikke blot kendt i Frankrig, hvor mangeurs de choucroute (surkålspisere) er et spottenarn til tyskerne, men også i Nordamerika, hvor man siger til de tyske indvanIrere: You are as Dutch as sourkrout! (I er så tysk som surkål!). Ligesom franskmændene bar ogsa italicnerne fiet et par dyr fra Tyskland, nemlig lo stambecco (t. der steinbock 0 : stenlukken), la martora (t. der marder $\curvearrowright$ : måren) samt $i l$ tasso (t. der dachs $\curvearrowright$ : grævlingen), og desuden bl. a. et så velklingende udråb som tasti tastondo!, der er en italiensk omæltning af tyskernes dass dich das donnerwetter!

Af större interesse for os er det dog, at ogsă et antal nordiske ord er nåede til fremmede lande og dèr endnu stadig finder anvendelse; således navnlig $\mathbf{i}$ England, Frankrig og Tyskland. I sidste halvdel af det 9. århundrede indtng danske sohelte hele det nordlige og østlige England, og store masser af danske bosatte sig dèr i landet, der efter dem fik navn af Danelag. Ganske vist antog de med tiden angelsaksernes sprog, men dog ikke uden at efterlade tydelige spor af den danske tunge. Navnlig det nordengelske almuesprog har indtil den dag $\mathrm{i}$ dag bevaret en hel nængde danske ord, silledes bl. a. benævnelser på planter som allars (elletræer), roan-trees (ronnetræer). lins (lindetræer) og big (byg) samt på redskaber som trow (trug; oldn: trog; sj: trow), greype (greb), liester (lyster $ว:$ redskab til at stange ål med), roek (rok), garn-windle (garnvinde) o. s. v. ${ }^{1}$ ) Men også i det

1) Jf. A. Fabricius: Illustreret danmarkshistorie for folket. Ny udgave 18\$9. Forste del, s. 123. 
nuværende engelske skriftsprog findes der nordiske ord som earl (jarl) og nithing (stakkel; vort: nidding) samt ill (ond, syg; vort: ilde), to take (at tage), og stedordet they - them (vort: de - dem). I det nordlige Frankrig oprettede den danske høvding Rollo 911 et hertugdömme, der efter de normanniske erobrere fik navnet Normandi. Også her gik de nordiske nybyggere over til de indfodtes sprog; men ligesom $\mathrm{i}$ England finder vi her adskillige sproglige vidnesbyrd om, at danske for tusende år tilbage tog bopal i landet. Den i Normandiet herskende franske dialekt har nemlig endnu så nordisk prægede ord at opviso som f. eks. bru (svigerdatter; rort: brud), bruman (brudmand $\odot$ : brudgom), loure (et blæseinstrument; af vort: lur), hambouiner (knæhas; jysk: hambugt, hamböjt), bar (bör, båre; oldn: barar, varir; sj: bar'), tro og trug (trug), quercan (træhalsring til køer og svin; kværkebănd), toque (tosset; jysk: tokket), tur (om jordbunden: tïr), vatré (våd; oldn: vátr), trogne (opsvulmet; oldn: prútinn af prútna o: svulme, horne; jf. sj: de trond'e) o. S. v.1) Desuden haves især et antal nordiske søudtryk, der også er gåede over i det franske skriftsprog, son houle (dönning, hulso), esquif (lille fartöj; vort: skib), varec (alt, hrad havet kaster op på kysten; vort: vrag), tillac (dæk; jf. vort: tilje), stribord eller tribord (styrbord), bîbord (bagbord), boulin (bugline), beaupr's (bovspryd), tolet (told $\mathrm{o}$ : åretold) m. fl. I Tyskland er det derimod ikke normannernes fard, men den fort-

1) Jf. A. Falbricius: Danske minder i Normandiet. Klbhv. 1897 , s. 330$)-3333$. 
satte berøring med selre de nordiske lande, der navnlig har gjort sig gældende. Specielt har det nordalbingiske plattysk optaget flere danske udtryk, isar fra det daglige lirs område. Jeg tænker her dog ikke pa det angelske plattysk, da der i Angel jo ikke er tale om indforte, men om bevarede masser af danske elementer. Holder vi os altså til egnene syd for det danske tungemåls oprindelige enemarker, så finder ri bl. a., at der ikke alene i hele Sydslesvig, men ogsả pă enkelte steder i Holsten bruges så kendelig danske ord som welling (rælling), klippen (at klippe) og flitten (flytte) samt flüttag, flüttzeit og flüttgut. Nede i Ditmarsken hedder tarskeloen ligesom hos os $l o$, og den dir endnu brugelige "tingstok" har navn af burstok, der ikke er andet end en forvanskning af det danske butlstikke. I den störste del af Holsten er ord som. boos (bås), lee (en le), füken (fyge) og spillen (spilde) almindelige, og i hele Holsten siger man kratt (krat, kratskov), grums, stakkel og stakkels. ${ }^{1}$ ) Atter andre nordiske ord har vundet endnu stiorre udbredelse $i$ Tyskland, idet de er optagne i det tyske skriftsprog. Sáledes er landbohl- og insten-stelle (af bol og inderste э: indsidder) optagne $\mathrm{i}$ det prïjsiske embedssprog. I tyske verdenshistorier og ordboger kan man læse om skulden (skjalde) og wikinger (vikinger). Fra havets område findes overforelser som sund (sund; oldn: sund), belt (bælt; oldn: belti o: hrlte) og fjord cller fïlerde

1) Jf. professor Johannes Krey: „Die diunische sprache in herzogtum Schleswig" i "Jahreshericht der kgl. realschule zu Sonderhurg für das schnljahr 1899-1900. 
(fjord; oldn: fjörðr). Fra den nordiske dyreverden haves renntier (rensdyr, ren: oldn: hreinn) og formodentlig vieltrass (jærv), der menes at være en sammensæetning af de nordiske ord fjell (fjæld) og fress eller fross (hankat) og altsi ikke at have noget med det tyske viel (meget) og fressen (æede) at göre, samt walfisch (hvalfisk, hval; oldn: hralr), narucul (narhval), hvis ligblege farve har givet den navnet (olln: nár $n$ : lig, dødning; altså: dodningehval), og hummer (hummer; oldn: humarr). Valfiskefangsten dreves allerede $\mathrm{i}$ det 9. århundrede af nordmandene, og de fleste og tillige de bedste hummere lever ved den norske kyst. Og endelig har jeg et lille eksempel på, hvorledes en nordisk betegnelse i nyere tid er i færd med ad skriftlig rej at gå over i det tyske sprog. En dag for et par år siden vilde min hustru nede i Rostock kobe en dase "benfri sild", og hun spurgte derfor en kobmand, om han havde „entgrätete heringe". Manden rystede ${ }^{\prime \prime}$ hovedet; dem kendte han ikke. IIen efter at han sa havde fảet en nærmere beskrivelse af varen, udbred han pludselig: „Ach so, Sie meinen appetits-silt? Han bragte derpi en af de onskede diser, og det viste sig da, at der på denne var klæbet en etiket med påskriften „Appetitsild“; den rar nemlig importeret fra Norge.

Det er altså med ordene i de enkelte sprog, som det er med forskellige landes produkter: der finder $\mathrm{i}$ talrige tilfælde en gensidig overforelse sted; der eksporteres og inporteres. Og hrad særlig de importerede 
produkter og det indforte ordforråd angår, kan sammenligningen drages endnu videre: ligesom vi nemlig blandt de udenlandske varer kan skelne imellem nodrendigheds-, bekvemmeligheds- og luksus-artikler, vil vi også blandt de fremmede ord finde flere, der horer til vor daglige brug, adskillige, der tjener til at lette os udtryksmåden, og nogle, der loruges til både at pynte og prale med. Men ligesom et land jo dårlig kan besta ved import alene, men forst og fremmest må se at drage nytte af sit eget omrides frembringelsesevne, således kan også et sprog, når det da skal fores en sund og selvstændig udvikling imøde, kun målelig nöjes med tilskud af ord, dor kan hentes fra fremmede mål, men må selv skabe nye værdier ved lijælp af det stof, som det har til sin rådighed inden for hjemlandets grænser.

Lad os da se, hvilke hjemlig e kilder til ordforrådets foregelse der haves at ose af.

En af disse kilder er den os omgivende n atur, hvis tusendstemmige sprog vi har mangt et betegnende udtryk at takke for; det er de såkaldte onomatopoietiske eller lydmalende ord som f. eks. svup!, et suup, at siuppe eller pik!, et pik, at pikke og en pikkepik (i barnesproget: et ur) o. s. v., jeg tænker pà.

Sådanne lydefterlignende ord er ligesom et umiddelbart ekko fra menneskets hjærne; de er oprindelig et udslag af den menneskelige efterlignelsesdrift, og da denne $\mathrm{i}$ reglen formindskes med tiltagende åndelig udvikling, ligger det nærmest, at mange af vore almindelige lydord alleredo er dannede $i$ den grảeste oldtid. Men da der på den anden side endnu 
stadig er mulighed for at berige de enkelte sprog med tilsvarende nydannelser, vil det for de flestes vedkommende nappe kunne afgöres, om de er ældgamle eller af farholdsvis nyere oprindelse.

En del af de omtalte udtryk tjener til betegnelse af selve naturlyden. Vi taler således om bakkens rislen, ildens knistren, sporens klirren, lorets raslen, tordenens rullen og vindens tuden, og vi lader sneen knirke under fodderne, anden plaske $\mathrm{i}$ vandet $\mathrm{og}$ vognen rumle på træbroen, medens

det suser i Nordens skove

og biuser fra dybe hav.

Ingen er i tvivl on de pagældende ords betydningr, när der meldes om slangens hvislen, froens krcekken, hundens knurren, biens summen, björnens brummen og lovens brölen, og ethvert barn ved, at gåsen hoceser, hönen kagler og duen kur'er, medens

storken klaprer på bondens tag

og iovrigt

fuglene sjunge

hver med sin tunge: pippip, kukkuk!

Det er ligeledes altid med en levende forestilling af, hvad det drejer sig om, năr vi blot horer ord som et hiin, et gisp, et $g y l p$, et klynk, et klask, et smask, et knas, et stamp, et kluk, et skvulp, et drön o.s. v. Af lignende specielt sønderjyske ord, der næppe har hjemme $\mathbf{i}$ rigsmålet, kan nævnes et vip, et knyst, et bak (pa piben), et bolk, et rup, et dummer o. l. Jeg behover for de kongerigske læseres skyld dog vist næppe at tilfijje betydningen; den fremgår, tænker jeg, tydelig nok af de enkelte ords fra naturen hentede lydindhold. 
Thi de samme naturlyd opfattes vasentlig ens overalt oy til helt forskellige tider. Således lader den græeske lystspildigter Kratinos (død 423 f. Kr.) fårene bræge bith, og hans samtidige kaldsfælle Aristofanes lader hunden sige hav og froen broklis holks, horkis kouks, medens han gengiver en af nattergalens talrige triller med forotorotorotorotiks torotorotorotorolililiks. Det er derfor et sarkende for de lydmalende ord, at de ofte genfindes under samme eller væsentlig samme form $\mathbf{i}$ băde geografisk og historisk adskilte tungemaal. Et par eksempler vil uden vanskelighed godtgöre dette. At pippe som en fugl hedder på svensk pipu, på tysk piepen, piepwen, på engelsk pip, på fransk pépior, pâ latin pipure, pa græsk pipizwin og titizein; det danske lirisle er sv. lurissla, ty. zischen, eng. siss, sizzle, fr. siffer, lat. sibilure, gr. sizrin; at krygle som en höne er sv.

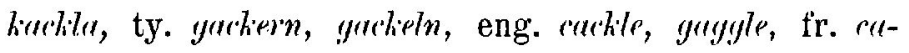
furter, lat. corrolume, corhinmare (også on mennesker), gr. kuklazein; at krwhke som en fro hedder sv. sqräki,

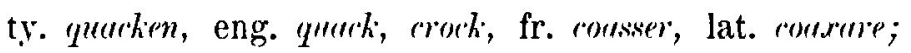
at yurgle er sv. gurylu, ty. guergeln, eng. yungle, fr. guryuriser, gr. gungurizein, og mumle bliver sv. mumlu, ty. mumeln, eng. mmomur, mumble, fr. mummerer, lat. murmmire. Undertiden afviger selve lyden $\mathrm{i}$ de forskellige sprog noget mere, men forbliver alligevel karakteristisk; således hedder f. eks. at skrige som et svin på ty. quirken, quietsrhen, eng. squenck og gr. koizein; at minske er sj. rymme, sv. gnägy", ty. wiehern, eng. whinny, fr. hennir, lat. hennire; at hriske bliver ty. fliistern, flistern, eng. whisper, fr. clubhoter, lat. sussurore, gr. psithyrizein, og at summe som en bi eng. hum, fr. 
bomrlonner, lat. bombum facere, gr. bombein. Endvidere kan mærkes ty. krärluzen og gr. krozein (skrige som en vild fugl), ty. gurren, eng. coo og fr. roncouler (kurre), gr. kokkyzein (gale som en hane) og ty. melken, fr. muyir (også bengler), lat. mugire (og boure), gr. mykissthmi log boim) for det danske böle som en ko, samt da., sv. ng tysk kling, eng. clung, lat. clengor, gr. kllongygê og ty. schmutz, eng. smmk, sj. smuk (smækkys). Og endelig skal anfores, at handlingen at hilike på engelsk hedder lucchup og på suahelisk krikre, at suahelerne kalder "at hoste" kolum og "at nyse" tschufi, samt at det sidstnævnte ord hos gallaerne hedder hu;ifu! tegnene; og ! betyder visse for en del af do sydafrikanske negersprog ejendommelige smækkelyd, der ved at indsættes på rette sted får det anforte ord til at lyde omtrent nöjagtig, som når man nyser.

Helt ofte har man imidlertid overført sådanne naturlyd som benæunelser pa selve de lydgivende legemer. Vi behøver jo blot at trenke p̊ ord som en skrmlde (sv. shirllic, ty. schenarr), en tromme (ældre dansk bamble, oldn. lumble, eng. drum, tom-tom, fr. tomblomer, gr. tymummon), det tyske gurypl og det latinske guryulio (strube) og vort sonderjyske et kllrsk (piskesmæld). $\mathrm{P}$ a lignende måde hedder f. eks. "trommer", „klokker" og "lænker" på kinesisk henholdsvis kren-kum, tsium!ytsirm!y og tsiceng-tsimm og i mandschusproget tumy-tung, tuny-triny og kiling-hiling. Blandt de levende lydkilder, der $\mathrm{i}$ visse sprog har fiet deres navn efter den lyd, de plejer at udstøde, kan nævnes menneskaben, geden og katten: menneskeaben eller den såkaldte gibbon hedder nemlig på grund af det ou-out-oa, som den med 
forskellig betoning oftest anvender som udtryk for forskellige sindsstemninger, hos de indfødte på Java simpelthen $o u$, gedens navn er på grönlandsk mek, og katten kaldes både på kinesisk og ægyptisk ligefrem mjir. Men især har mange fugle fảet navn på denne måde. Et af de mest fremtrædende eksempler er gogen; det tyske kwckwck, det engelske mulioo, det franske. rom'ou, det latinske curulus, det græske kohys, det sanskritske kolillıs og det finske kwhkwju lader es ligesom vort sonderjyske kithl' uden videre genkende fuglens ensformige råb. Hanens hyppigste lyd er kok-kiok-kiok, og den hedder da også på sonderjysk kok, på engelsk corch, på fransk roq og på trsk yochel. Ikke mindre tydelig genkender vi twttr-duens kurrende twtur i dens forskellige navne; den hedder på sv. turtur-dufva, ty. tuito-taube, eng. twotle, fr. tourtie, ital. tortore, lat. turtur. Kra-gen skriger krr-kww, og dens tilsvarende navn er da hos os kirug', i Sverige "kråka“, men tidligere krrkki, i Tyskland „krähe", men tidligere chrịja, krâue og kin, i Svejts krok og i England cromr, medens den med kragen beslægtede „kä“ (allike) af de gamle romere kaldtes yruculus. Spurr-ens advarselsråb er sprrr, og den bedder derfor på tysk sper-ling, på engelsk spurr-ow, på svensk wawif og på sonderjysk grå-spur. Ligeledes genfinder vi ug-lens tudende råb i flere af dens navne: sv. uf, ty. uhu, buhu, schuhu, osmanisk bugu, fr. hibou, lat. bubo, ulula og gr. ololygôn. Bogfinkiens muntre lokketone fink eller pink er let genkendelig i betegnelserne fink' hos os, fink i svensk og og tysk, finch i engelsk og pincon i fransk, medens en af dens triller, der begynder med fri . . ., har givet 
anledning til dens latinske navn fringilla. Påfuglens gennemtrængende skrig pao har bevæget romerne til at kalde den parn, der $\mathbf{i}$ fransk er blevet til paon, $\mathrm{i}$ tysk til pfun og hos os til pri-fugl. Endvidere genkender vi stillids-ens lokketone stillit foruden $\mathrm{i}$ dens almindelige danske navn $\mathrm{i}$ det sønderjyske strilisken, det svenske steglitsa og det tyske stieglitz, samt vib-ens klagende skrig i sj. vif', sv. vipu, ty. kiebitz, plt. kiwitt og fr. dial. dix-huit. Og betegnende er det endelig, at en pippende fugl på latin hedder pipio og på græsk pipos (jf. vort piphans om en kanariefugl), samt at den skrigende skovskade i Norge kaldes skrike. - Også kukmlumps navn og sædvanlige råb stemmer meget nöje overens med hinanden; men her er forholdet omvendt: det er ikke fuglen, der har fået sit navn efter råbet, men det er dens malajiske navn kitkituu (egentlig: lille fa'r), som de fleste tæmmede arter har lært at snakke efter; af utæmmede fugle horer man det aldrig.

Foruden de således berorte almindelige lydmalende udtryk findes der trindt om talrige mere specielle, der ligesom hører til orddannelsens vilde skud pæ det her betragtede område. Også disse har krav på et ijjebliks opmærksomhed, så meget des mere, som de byder os lejlighed til at iagttage den menneskelige efterlignelsesdrift i umiddelbar virksomhed.

Når i sin tid hanen hos os er bleven opkaldt efter sit idelig gentagne $k \rho k$ og katten hos kineserne efter sit $m j \omega c$, så er dette fanomen jo af selvsamme art, som når enkelte folk, der er komne i vane med păfaldende ofte at gentage visse ejendommelige lyd eller udtryk, pådrager sig et til vanen eller uvanen svarende 
øgenavn. Således mener man jo, at kong Valdemar den tredje af Danmark har fået sit tilnavn Atterdag, fordi han plejede at bruge det mundheld: „I morgen er det atter dag. ${ }^{*} \mathrm{P} a ̊$ lignende måde har franskmændene hos beboerne af enkelte øer $i$ det stille ocean faet navnet wi-wi; Frankrig anvender nemlig Ny-Kaledonien til straffekoloni, men det hænder ikke saa sjælden, at forbryderne undviger over til andre øer, og disses oprindelige beboere giver da franskmændene det omtalte navn, fordi de så ofte hører dem sige oui oui (ja ja). Vi behøver imidlertid hverken at gå over et halvt årtusende tilbage $\mathrm{i}$ tiden eller om på den modsatte side af jordkloden for at få flere eksempler. Jeg mindes f. eks. to $\mathrm{nu}$ historien tilhørende latinskolelærere, af hvilke den ene, som følge af sit hang til jæernlig at lade en hyssende lyd suse ud mellem tænderne, af skolens elever havde få日t tilnavnet $S y s$, mens den anden, på grund af sin udprægede forkærlighed for brugen af det tyske adverbium eben (netop) i vendinger som "eben da", "nun eben", „eben also" o. l., aldrig kaldtes andet end Elben; da den forstnærnte bl. a. underviste i græsk og den anden $\mathbf{i}$ hebraisk, var de nævnte to ogenavne så meget des mere tiltrækkende for de pågældende elever, som det græske ord sys betyder "svin" og det hebraiske aben en "sten". Et næppe så "lærd“ men derfor ikke mindre betegnende tilnavn har i den nyeste tid desuden en nu ligeledes afdød sønderjysk tækker Jørgen Kristensen selv givet rigelig anledning til. Han havde nemlig den mærkelige vane, når han talte, idelig mellem ordene at udstøde en lyd, der nærmest kan betegnes ved ie; således plejede han bl. a. at henvende 
folgende opfordring til karlene eller drengene, der hjalp ved tækningen (ved „a stik ue“): „Hal ip, hal ir, træk ir, stik if, o e krog skal gaa klask ir klask ir, så komme de imme fort i $\rho^{*}$ " Hvad under da, at de fleste, og navnlig ungdommen, kaldte vor tækker Jöen Ir? Han protesterede ganske vist, men selve protesten blev kun årsag til ogenarnets yderligere fastnagling; thi når drengene f. eks. sagde "Godaw Jöen Ie", sä srarede han, tro mod sin rane: "dE jerre itt' Jöen IP ir. men $\circledast$ jerre Jïen $\bar{i}$ ristensen ie!"

Et andet og særlig betegnende udslag af menneskets medfodte trang til naturefterlignende narnedannelse finder vi i börnenes $\mathrm{måde}$ at tale på. Mindre börns lyst til at give deres tanker og folelser luft er i reglen overordentlig stor, og da navnlig i forhold til det forråd af ord, der står til deres rådighed; når derfor dette slipper op for dem, griber de gærne til en eller anden slags særegen dannelse, og blandt disse da også til onomatopoietiske udtryk. Det er jo almindelig bekendt, at en ",hund", en "gred" og en ,and" i börnenes sprog uden videre hedder rou-vou, mokklie-mok og $r(m)-r(b)$. Blandt mindre almindelig kendte eksempler kan nævnes, at to små saskende ifølge Axel Kock bestandig kaldte „diskanten" og „bassen“ på klaveret for hlinkien og bommen; de substantiverede altså bi̊de vort lydefterlignende udsagnsord klinke og det ligeledes fra naturen hentede bom! Det forekommer imidlertid ogsa, at det ikke er indtryk gennem oret alene, men desuden forskellige indtryk gennem öjet, som bürnene seger at symbolisere ved at anvende tilsvarende ulige sproglyd. Sialedes omtaler Georg v. d. Gabelentz en 
lille tysk dreng, der vokaliserede ordene på ulige måde, alt eftersom han vilde betegne större eller mindre genstande. Jo större genstanden var, des dybere vokaler betjente han sig af: en sædvanlig stol hed på hans specielle sprog en lukeil, en stor lænestol derimod lukiul og en lille dukkestol endelig en likill. Runde ting betegnede han $\mathbf{i}$ almindelighed med roden $\mathrm{m-m}$, men han anvendte denne med flere variationer: både manen og en sædvanlig tallerken hed mem; et stort rundt fad betegnedes med mom eller mum; men de mange små stjærner på himlen kaldte han mim-mimmim-mim-mim. Til sin fader sagde han sædvanlig $p^{\prime \prime} p^{\prime \prime \prime}$, men da han en dag så faderen i hans store pelskappe, forekom denne ham sỉ vældig, at han kaldte ham mume.

En langt righoldigere hjemlig kilde til ordforrådets forøgelse er imidlertid selve sproget i sin tidligere og nuværende skikkelse.

Betragter vi i forste riekke det danske rigsmả l, să ser vi, at dette har fået en betydelig tilvækst ved bade at optage gamle betegnelser enten fra den ældre danske literatur eller landets forskellige dialekter og navnlig red at danne et stort antal nye værdifulde ord af sit eget almindelige sprogstof.

Af de fra den ældre literatur og folkemalet o $\mathrm{p}$ tagne ord har de forstnæunte iswr vundet adgang til digtersproget. Dette er f. eks. tilfaldet med drot, leding, ral, brynje, glurind, lijulte og hal, shjold, drripur,

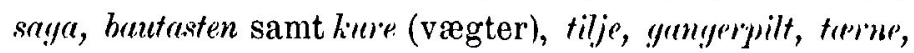
liljerand, mair, fore (adferd), rem, faugr, bold, prud, dan- 
nis, $y s k$ o. s. v. De har alle med hverandre ligesom et præg fra fordums dage, hvad enten de bringer os bud fra vor helteold eller minder os mest om hin senere tid, da „i borgens gyldne sale sig rorte muntert liv". De har derfor også beraret en vis höjtidelig klang, der gïr dem mindre skikkede til at bruges pä liverdagslivets område. Blandt dem af vore digtere, der i större eller mindre omfang har genoplivet disse og andre fordeldede udtryk, kan nævnes Johannes Ewald, Klavs Frimann, Edv. Storm, Jens Baggesen, Oehlenschlæger, Blicher, Ingemann, Grundtrig, Hauch, J. L. Heiberg, Poul Moller, Chr. Winther, Henrik Hertz, Fr. Paludan-Moller, Carl Ploug; Edv. Lembke, ('hr. Richardt o. fl. Af större betydning er dog de mange dialektord, der $\mathrm{i}$ de sidste menneskealdre er blevne indlemmede $\mathrm{i}$ skriftsproget ved at anvendes af talrige forfattero lige fra Blicher, Grundtvig og Chr. Winther til Schandorph, Drachmann, J. P. Jacobsen, Gjellerup og H. Pontoppidan. Hror stort dette tilskud har veret, kan man få $i$ det mindste en anelse om red at se, at J. Junge $i$ sin bog om „Den nordsjællandske landalmues karakter, skikke, meninger og sprog" 1824 anforer goll, grăsten, hjolmet, knos, mornyttiy, omyımyssygr, orlor, pos, rusme, på sned, et stomyp, at titte o. s. . som horende specielt til det sjællandske folkemăl, samt navnlig ved at bringe i erfaring, at Chr. Molbech endnu 1841 bl. a. opregner folgende dialektord: at lijerye, bjoryom, at erne, ficele, frerdes, forstrmuml, at grontw, en lominy, omtanke, sidelcpns, at stumli, sy $u$ s. 0 . s. $\nabla$., om hvilke lian udtaler det onske, at de „i en eller anden retning kunde vinde adgang $i$ en 
videre kres eller forøge skriftsprogets ordforråd". Siden da har de anforte ord jo unægtelig tabt deres særpræg som bygdemålsudtryk. Og det samme mă siges om et antal ord, man kan træffe $\mathrm{i}$ tidligere beskrivelser af sønderjyske sprogforhold; således i Knud Aagaards „Beskrivelse over Torning len“ 1815: yill (artig) og lod (farve), i Hagerups bog "Om det danske sprog i Angel" 1854: whild (æbletræ), bing (stor trækasse med lăg) og harde (skulder) og i Johannes Koks "Det danske folkesprog i Sønderjylland“ 1863: ful (led, hæslig), krrving (tvebak), krrerle (halssygdom hos heste, krop), at tarlye (snitte), rellirtst (brændestabel, oplagssted for brændsel under åben himmel) o. s. v. Disse betegnelser står $\mathbf{i}$ de omtalte boger anforte som særlige almueord, og de har altså den gang, i det mindste for de pågreldende forfatteres bevidsthed, ikke haft præy af alnindelige rigsmålsudtryk; men nu til dags finder ri dem alle $i$ de fleste af vore nyere danske ordboger: både i Svend Grundtvigs håndordbog, der soger ,at give en tilnærmelsesvis fuldstændig fortegnelse over alle i det danske rigssprog hrugelige ord", og i Saabys retskrivningsordbog, der som sådan jo kun tager hensyn til skriftsproget, samt endvidere i Sundbys og Baruïls dansk=norsk-franske og i Kapers dansk= norsk-tyske håndordbog uden $\mathrm{i}$ disse at være betegnede som norske, provincielle eller dagligdags udtryk. Det skal hermed dog ikke være sagt, at de sidstnæunte ord er tagne specielt af det sonderjyske landsmål; thi de forekommer også både $i$ almindeligt jysk og $\mathrm{i}$ andre danske dialekter; ja de findes endogsă adskillige steder $\mathbf{i}$ ældre danske skrifter, og det vil der- 
for $\mathrm{i}$ de fleste tilfælde vist være vanskeligt at afgöre, om det ved indforelsen af disse og lignende ord $i$ vort nyere skriftsprog er et af nutidens almuemål eller fortidens literatur eller muligvis samtidig begge disse dele, der har tjent som kilde.

Mindst lige så vigtig er imidlertid sprogets berigelse med helt nye ord, der enten ved afledning eller sammensætning er dannede af dets eget forhåndenværende grundstof. Ved sådanne nydannelser er det danske skriftsprog blevet foroget gennem alle perioder af dets tilværelse; men navnlig har dette været tilfældet i nyere tid, og talrige nu almindelige ord turde være betydelig yngre, end mange formoder. Hrem der ikke har haft lejlighed til at göre sig nærmere bekendt med vort modersmåls historie, vil vistnok finde det påfaldende, at ord som storhed og arefrygt kun er 150, sognerůd og doldsbo næppe 100 og levedygtig og rejrbidt end ikke 50 år gamle. I året 1765 skrev Charlotte Dorothea Biehl en komedie „Hårkløveren“, Lvori elskeren ikke bliver forstået, fordi han bruger "nymodige" udtryk som bisager, fordomme, lidenskaber, omdömme, indsiytsfuld, orerdreven, virksom o. s. v. 1793 omtaler Rahbek forelobiy som et nyt ord. I fortalen til „Videnskabernes selskabs danske ordbog" (1. bind 1793) forkastes ordet genstand som "selvgjort", og endnu efter 1807 vilde Kierulf have ordet indlysende udelukket af ordbogen som barbarisk og ganske overfledigt. J. P. Mynster omtaler 1853 ordet honedsayeliy ironisk som et "nydeligt“ ord fra den nyeste tid, J. Levin kalder ordet iherdig ,et skandinavisk fjanteri fra Kristian den niendes tid .... det spoger engang imellem 
i Dagbladet 1865“, og E. Jessen mener 1893, at „fabrikatet fremtoming kan ikke anerkendes for at være et ord." Af andre nyopfundne ord, som fra forst af lejlighedsvis er benyttede af enkelte forfattere, men senere har vundet almindelig udbredelse, kan f. eks. nærnes: indbildningwkraft (Eilschow), rindskibelighed (Sneedorf), fraitund (P. K. Stenersen), omegn (Rahbek), liemlig (Baggesen), repytfylde (H. C. Orsted), drrisk (Soren Kierkegaard), fmmilstjenliy (Erik Bogh) o. s. v. Det er imidlertid langt fra altid, at den slags nydannede ord vinder bifald; således er hverken $O$. Hammers jurmidlablende for "parallel“ (1772), H. C. Orsteds fjurushrift for "telegraf" eller H. P. Selmers ildlmrmmeri for "artilleri“ (1861) trængte igennem. Uheldige er desuden enkeltvis forekommende nydannelser, der som kreuturforsikingsforeningshestyrelsesmedlemmer har en alt for afskrækkende længde; den slags sammenlinkninger er unægtelig en misbrug af sprogets overordentlige medgerlighed.

$P$ \& lignende måde som rigsmålet forøges også dialekterne jæernlig ved hjemlige tilskud og nydannelser.

Ligesom det danske skriftsprog har fået en betydelig tilvækst fra landets forskellige bygdemål, săledes har disse til gengæld o p t a g e t talrige ord og vendinger fra skriftsproget. I sonderjysk bruger vi sáledes ofte en hel del udtryk, hvis rigsdanske herkomst vi ligefrem kender. I året 1780 skrev C. (\% Birch i sine „Tanker om en prækens egenskaber for tilhorere pa landet". at "mange af vore i tidligere tider indforte danske ord ere endnu lige si ubekendte 
for bonden, som de var det for vore forfædre", og som eksempler anforer han formil, ajenstund, monster og bestemmelse; takket være den stadig voksende udbredelse af danske bøger og blade er disse og lignende ord nu så langt fra at være belt „ubekendte for bonden", at de endogså, i det mindste hos os, ret jævnlig høres i dagligdags (sonderjysk) tale. Det samme kan siges at gælde om ilt og lrint, der er dannede af H. C. Orsted, samt on ordforer, andraymenl, cmdringsforslum, udraly o.s. v., der i deres skriftdanske, men jo kun til dels, og da meget ubetydelig afvigende form er fastslaede af den danske rigsdag, altså efter 1848. Enkelte andre i sønderjysk brugelige ord og talemader forråder ved formen alene deres rigsdanske oprindelse. Dette er f. eks. tilfældet med sammensætninger som forglemmigej (myosotis), lymurlenler, prishind og uaffodle samt udtryk som "ikke sandt“, "sodle moer", urren undtagels" og "de kan nok sit! humll", eftersom de sonderjyske former for "mig", "lyn“, „på“, „af“", „ikke“, „søde“, „tage“, „sig“ og "hænde" jo ellers er mip, lyssen, ac, arr, itt', si'e, trej", so" og hwend". En "pjalt" og en „dukke" hedder på sonderjysk pollt og dolk', men alligevel kalder vi en mand, der let lader sig skræmme til at handle mod sin overbevisning, en pjalt, og én, der uden at lade det komme til en egen overbevisning, straks siger ja og amen, en nikkedulike. Fra rigsmålet stammer selvfolgelig endvidere brugen af et par med det redhængte bestemte kendeord -en forsynede narneord $i$ vendinger som „no hær $æ$ ald'e kænd ma'grn", „fò restem", "fuj fo kitten" og "gid dïr'lm annamm' ham". 
Men i lighed med skriftsproget har også vort sonderjyske mål i sit eget almindelige grundstof do bedste betingelser for en fortsat udrikling af nye selvstændige betegnelser. Dette gæelder både med hensyn til afledning og sammensxtning. Af udsagnsordene fol'le (folge), yeett' (gatte) og rrar'e (rode) afledes navneordene fol'lest (folgeskab), grmt'trls (gade) og rridsel (pusling) i lighed med "hyldest", "stroelse" og "gærdsel" af ,hylde": ,stro" og , ,gærde", og ved endelserne -ing og -ning dannes ord som loming (lunt sted), bres'ning (skillevæg mellem to háse) og slir'ning (langdrag). Endelsen -end kan föjes til et hvilket som helst udsagnisord og derved göre dette til et narneord; man ternke f. eks. på „et sæellet yureml.", ,et lamp'le r'ymd", ,et ba'ste $n y '$ 's'md", ,et landt sprlik lriem/" o. s. v. Denne dannelsesmåde er altså langt mere udbredt $i$ sonderjysk end $i$ rigsmålet (jf. et foretagende, forlydende, vidende o. l. a.), hvorimod den nïjagtig svarer til brugen af -amde og -rmde i srensk, hvorom M. Strömberg i sin svenske sproglare skriver: "Medelst ändelsen -rmde, -end kan ett substantivum bildas af hvarje verbum." Ligesom vi i rigsmălet har tillægsordene ,gængs", "lobsk" og ,kælen": af ,yang“, „lobe" og ,kæle“, således har vi i sonderjysk nylis (stodt, fornærmet) og howres (morsom) af $n y k$ (stod) og hour're (,huro"; rm. mo(d)ro), fyrmdsk (som grunder, melankolsk) og remdsk (som mangler, begærlig) af groend' (grunde) og 'rmt' (mangle) samt misen (ophovnet) og rrejn (vranten) af res' (rejse, hæve) og midl' (vride); og ved hjælp af endelserne -lr (lig), $-x(m),-m m$, og -mrde (agtig) dannes mange sỉ ejen- 
dommelig sønderjyske tillægsord som $a f^{\prime \prime l}$ (abeagtig, naragtig), luml'le (let at håndtere) og fứl' (ganske fä), frrm'ssm (hvad der kan fremme), reme'som (hvad der hurtig forer til enden) og merk'som (i besiddelse af god hukommelse) samt dreng'rom (drengeagtig), ljer'rerorn (bjærgfuld) og mis'rom (som forvolder mas, beswerlig), og i lighed med rigsmålets "langagtig“: like'arde (temmelig lille), sild'arde (tenmelig sildig) oy srcri'turle (temmelig tung). Af ejendommelige udsagnsord kan næevnes lutt' (tage hatten af), limej' (være efter ens hoved), f. eks. "de horj' ham itt'; (det behager ham. ikke), "eent' (gå rask fra hånden, fore hurtig til enden), srewsk' (harve med svenskharve) o. s. v. Ikke mindre påfaldende er en del for vort landsmill sæeregne, men ikke des mindre rent danske sammensxtninger. Da i sin tid stænderne opkom, dannede de sonderjyske bonder $i$ steden for det tyskagtige "stænderforsamling“ det danske ord komy'yrund, den fra tysken stammende "bettelstav" hedder hos os en brej'lijup, og medens man i kongeriget bruger et nedertysk "vaterpas", har man i Sonderjylland lavet et godt dansk reme'mer'e. Hvem der ikke har noget tilovers for fattige folk, er en strkiklellec'rer (stalikellader), den hovmodige hedder sto'ehju'de, hvem der har erhvervet forsorgelsesret $i$ et sogn, kaldes sugnfinst, den morsomme, der bidrager til at forkorte tiden, er till'kotte, hvem der har overmaide hastværk, kaldes bi'lø.;, den energiske betegnes som yom'melsat'le, hrad der er inảen for skindet, er indenskinds (jf. rm. indendiirs), i steden for fjorgammel siges der ütercirs, og i overensstemmelse med rigsmålets "sidelangs“ daunes 
der talrige biord som rejlangs, by'lanys, ga'elangs, lms'lanys o. S. v. Hvor stor rort landsmáls erne til narnlig red sammensætninger selr at foroge sit ordforrad er, kan endvidere ses af den kendsgerning, at flere af de $\mathrm{i}$ den nyeste tid hos os indforte fremmede begreber til dels har fäet særegne sonderjyske narne: således kaldes f. eks. en "standesbeamter" (cirilstandsembedsmand) i reglen cirilymerst, en "amtsdiener" (amtstjener) tyer'troliter og "haftpflichtversicherung" (en slags erstatningspligtforsikring) rent folkeligt ben'brokliprlirss'.

Det går imidlertid med ordene i sprogets verden, som det går med de enkelte individer $\mathrm{i}$ planteverdenen. Ligesom planten fremspirer, lever og dor, siledes fremstår, lever og dor også ordet. Og ligesom visse planter, f. eks. egen og cypressen, kan opna en ganske overordentlig alder, medens andre, som nogle af vore almindelige skimmelsvampe, må gennemgå alle deres udviklingstrin pi en eneste dag for atter at do, inden denne er til ende, således er også ordenes tilværelse af yderst ulige varighed.

Ja aldersgrænserne strækker sig i ordenes verden endogs̊̊ lidt videre til begge sider end $i$ planternes.

Ved at tælle årringene p̊ fældede kaliforniske kæmpecedere lar man fundet, at mange af disse „skovenes mammuter", som de ogsa kaldes, er tre til fire tusend år gamle. Men vi har. ord i vort sprog, der sikkert har levet endnu længere. Således genfinder vi f. eks. ordet mus ikke blot i oldnordisk, oldhöjtysk og 
oldslavisk (oldn. mus, oldht. mus, oldsl. mysi), men desuden i latin, græsk og sanskrit (lat. mus, gr. mys, sanskr. mush). Det anvendtes altså allerede i den gråeste oldtid, da indernes, grækernes, romernes, slavernes og germanernes fælles grundsprog endnu ikke var spaltet $\mathrm{i}$ flere dialekter. $\mathrm{Og}$ pd den anden side lever den kortvarigste skimmelsvamp længere end mangt et ord: thi den bruger dog timer til at fremspire, vokse og visne, hrorimod talrige ord har fundet deres dod i det samme noment, de er opstaede. Jey tænker herved på de halvt eller helt ubevidste nydannelser, der mangen gang skabes for senere ikke at anvendes mere, og som den talendes omgivelser lige sả lidt som han selv lægger vægt $p^{\mathfrak{a}}$ at bolde i minde. Frem for alt galder dette om overmåde mange af barnesprogets ofte ret djærve men stundom slet ikke s̊̊ dårlige nydannelser.

Ses der imidlertid bort fra den slags öjebliksspirer i sproget, kan årsagen til, at et ord visner hen og gar ud og at derved altsa ordforradet formindskes, enten måtte søges $i$, at det pågacldende begreb har ophort at leve blandt folk, eller ogsa $i$ den omstæendighed, at ordet for sig, uden tab af begrebet, er blevet fortrængt af et andet.

Vi har forhen set, at et nyt ords optræden i sproget som oftest er et tegn pa fremskridt i kulturen; men oysi tabet af et ord som folge af selve begrebets forsvinden kan vidne i selvsamme retning. Denne påstand vil vistnok ved forste öjekast forekomme en eller anden en smule betænkelig, eftersom tab af begreber kan synes at være det samme 
som mindskning af menneskelig viden; men dog er det virkelig således.

For at godtgüre dette vil jeg forst pege hen til et par af de mest iöjnefaldende eksempler fra det moralske livs, og da navnlig fra tros- og folelsesytringernes område.

Selv med den mest udprægede höjagtelse for alt det storladne og virkelig store, der udmærkede vore hedenske forfædres tænkemåde, må enhver dog glæde sig over det fremskridt i almindelig oplysning, der ved kristendommens sejr over hedenskabet medforte afskaffelsen af visse til asalæren knyttede skikke og begreber. Der vil således næppe være nogen, der beklager, at han ikke ved personlig iagttagelse kan fit et begreb om, hvad mumllblot vil sige, men kun gennem boger kan skaffe sig en forestilling af, livorledes det gik til, nàr en gorle (offerprest) enten pi et re (offersted) eller $\mathrm{i}$ et hor (hedensk tempel) til Odins wre Wotele (ofrede) et menneske for senere at lade ham sænke $\mathrm{i}$ en blotkelde (en sump, hvori man kastede de ofredes lig). Eller mon nogen skulde onske sig flyttet tilbage til en tid, da man troede på yodemess blutisyi (offerpræsternes spadom af offerkvægets indvolde), molvernes sprimule (spåkvindernes profetiske ord) og sejdmmendens yollder på sejdllyollen (troldmandens sang på heksestilladset)? Imidlertid var det jo ikke lutter oplysning, der fulyte med kristendommens indforelse: tvært imod bragte den nye lære, som den indfortes hos os, en del skikke og indretninger, hvis senere afskaffelse næppe vil kunne beklages. Vi behøver jo blot at taenke pà den såkaldte jurnbyrrl, en uskyldig- 
hedsprøve, der navnlig bestod $\mathbf{i}$ at holde på gloende jærn. Man gjorde derved forskel på skudsjarn; som af den anklagede måtte bæres et vist antal skridt, forinden det "skødes" (kastedes bort), og trugsjur"n, som fra et afmålt stade skulde kastes $i$ et trug, og hvis dette mislykkedes, optages igen og kastes så længe, indtil det omsider faldt ned $\mathrm{i}$ truget. I „Skånske lov" hedder det om det førstnærnte: „Bær man skuzs iurn, tha skal han stighæ ni fiæt langt før æn han skiutær iarn. Skiutær han iarn før, tha ær han fældær". Og om det sidstnærnte siges der: „Bær man trughs iorn, tha skal trugh standæ tolf fiæt fran stavæ, oc lin, ær bæræ skal, kaste iarn i trugh. Faldær iarn utæn trugh, tha skal hin, ær bær, up takæ oc atær kastæ i trugh." Da man imidlertid opfandt flere salver, som sikrede vedkommende mod at forbrændes af det gloende jærn, tabte denne "gudsdom" efterhånden sin anseelse; den blev i Danmark afskaffet ved lov af Valdemar den anden, og samtidig med, at som følge deraf de pågældẹnde begreber udslettedes af folkets bevidsthed, forsvandt også ordene af sproget. Senere, ved reformationen, afskaffedes andre af det katolske kirkevæsens indretninger og dermed betegnelserne for dem: titler på renlivede personer som kannik og prior, forskrifter som colibat og tonsur, ydelser som peterspenge og vigilier samt redskaber som rosenkranse (også psalterbaind eller himmeltrapper) og vievandskoste har hos os nu kun hjemme $\mathrm{i}$ historien, medens skytshelgene som Sankt Antonius, der var svinenes patron, eller Sankte Lucie, der var god til at at påkalde for öjenværk, er henviste til almanakken, og relikvier som stykker af 
Arons stav eller trin af den stige, Jakob så i drömme, fra klostre og kirker er vandrede til raritetskabinetterne. Andre overtroiske forestillinger, der ikke så meget berører den kristne lære, som de har deres rod i det gamle hedenskab, er ligeledes mere eller mindre forældede: havmoend og ellepiger lever jo endnu kun i poesien, og underboer (sj: ynd'ebosser), varulve, damheste, kirkelam og valravne forekommer kun i vore folkesagn.

$\mathrm{På} \mathrm{lignende} \mathrm{måde} \mathrm{er} \mathrm{andre} \mathrm{begreber} \mathrm{og} \mathrm{dermed}$ de tilsvarende betegnelser i tidens lob gået tabt $p \AA$ grund af den voksende humanitet. Dette gælder navnlig for visse tortur- og straffemetoders redkommende. Torturen, eller anvendelsen af legemlige pinsler for at tvinge formentlige forbrydere til bekendelse, er kommen til os over Tyskland fra Italien og har navnlig i det 16. og 17. årbundrede, da en udpræget grusomhed parret med religios ufordragelighed beherskede sindene, bragt en umådelig mængde uskyldige mennesker på bålet. Den afskaffedes endelig i sidste halvdel af det 18. århundrede i de fleste evropæiske lande, og siden da har torturredskaberne været henviste til musæerne og deres navne til ordbøgerne: ord som tommeskrue, spansk stövle og strcekkebcenk hører heldigvis ikke til den levende del af vort ongangssprog liengere. Og det samme er jo gud ske lov tilfældet med navnene pa mange af fortidens straffemidler. Der er vel næppe nogen, der vil fortryde ikke i praksis at kende Kristian den sjettes sabbatsforordning af $\mathbf{1 7 3 5}$, hvori det befales, at bønder, der enten havde arbejdet om helligdagene eller ikke kunde betale de bøder, som 
forsömmelse af kirkegang havde til folge, skulde straffes med at stå i gabestokken, samt at sådanne gabestokke, d. v. s. pæle med halsjurn, skulde rejses på samtlige kirkegårde uden for kirkedören. Med bondens frigörelse og genoprejsning fulgte afskaffelsen af hundehullet, der sædvanlig var en mork og fugtig kælder $i$ et af hovedgårdens tårne, den spanske kappe, der bestod af et omvendt trækar med et hul i bunden til at stikke hovedet igennem, og som synderen måtte ga offentlig omkring med, samt truhesten, en skarphövlet, p\& höjkant stillet fjæl, som den skyldige sattes overskrævs på og således måtte ride, undertiden endogså med stene bundne ved fodderne, hvad der spottende kaldtes at give ham sporer på. Og endelig er nu ingen udsat for at lide så barbariske straffe som dem, der bestod $\mathrm{i}$ at kagstryges, lobe spidsrod, brcendemurties og radbreplkes, ligesom heller ikke længere nogen „liden Karen" sættes „i spigertenden ned“, fordi hun er dydig nok til ikke at föje "unge kongen".

Men ogsa på det mere materielle område kan tabet af ord være tegn pa kulturens fremskridt; jeg behover for at eftervise dette formodentlig blot at pege hen til et par eksempler fra landbruget og livet inden düre.

En af de ejendommeligste og mest fordærvelige sider ved fortidens landboforfatning var jordfællesskabet, der var nedarret fra de ældste tider og holdt sig hos os til henimod slutningen af det 18. århundrede. Det var navnlig fordærveligt, fordi det medforte, at en stor del arbejdskraft gik til spilde red jordernes adsplittelse og fraliggenhed fra gården og at 
ingen bonde kunde foretage sig nogen forandring eller forbedring af driftsmåden uden de ovrige bymænds samtykke. Som følge af fællesskabets endelige ophævelse har imidlertid ikke blot landet men også vort sprog forandret sit udseende. Før jordernes udskiftning var agermarken enten bolsjord, der deltes ved rebning, eller gribsjord, der ikke ved rebning var lagt til noget bol. Af engene hed én del kiendt eng, hvor hver mand vidste sit skifte, og én del bolseng, der hvert forår deltes ved lodtrækning. Uden for disse dele af byens jord la $\mathrm{i}$ reglen de såkaldte overdvev (fælled, urtefang, udmark), som ikke dyrkedes, men altid benyttedes til græsgang; i ældre tider opdyrkede de mere velhavende adelbonder sædvanlig et stykke af de odeliggende jorder, og dette, der betragtedes som særeje, kaldtes si̊ ornum. Bestemmelser om arbejdstid og driftsmåde toges på grandet (også vide, gadestueve o. s. v.), hvortil der blev sammenkaldt enten ved grandestok (nabostoh, budstikke, tingvol), ved tuden i byhornet, ringning med gadeklokken eller ved at slå pd̊ bytrommen, og hvorved oldermanden (også grandefoged, videfoged, knupfoged) forte forsædet. Vedtæuten, der dömtes efter, hed bylov, grandebrev, videbrev, og den fik lovsmagt derved, at alle forsamlede tog om oldermandens pind eller bysens kjwep. For samtlige forsönmmelser ikendtes der boder; regnskabet holdtes pa hver mands "pind" (talliestok, videstok, karvestok eller kn'pping) ved skurer, og säfremt en mand havde mod eller penge nok, kunde han gærne blive ved til „pinds ende“. Den vigtigste kommunale embedsmand næst efter oldermanden var vistnok bysmeden, hos hvem 
bonderne, når de skulde have smedet, mødte til smej"stöwn' for selv at trække bælgen og slå med forhammeren, og til hvem der årlig af hver bymand måtte ydes en slif'lijurre, fordi han holdt slibesten til almindelig afbenyttelse, ligesom degnen fik en ring'kjorre for at ringe. En anden betydelig embedsperson var den fælles byhyrde, der holdt byens samlede kvægflok i ave ved hjælp af sin ringlestav eller ranglestav (en kort stav med en tyndere kæp eller jærnstang ved siden, hvorpå der var trukket et antal raslende jarnringe), og som i reglen fik sin kost ved, ligesom skolemesteren og sognets fattiglemmer, at gå rundt hos bunderne i mading. Med fællesskabsvæsenet fulgte desuden en hel del gilder, vi nu ikke kender, såsom oldermandsgildet, der askeonsdag gaves af den gamle oldermand til ære for den tiltradende, trommegildet, som gjordes, når bytrommen blev flyttet, ju'vningsgildet i anledning af gadejordens udlejning, tyregildet, hvorved bytyrens fortjeneste omsattes i drikkevarer, moggilulet, der måtte fejres, når gødningen var kort ud, og tjeregildet, som ikke kunde undgås, når en i fallesskab indkøbt tønde tjære fordeltes blandt bymændene. ${ }^{1}$ )

En del lignende iagttagelser vil vi endelig kunne göre ved at kaste et blik på livet inden döre; ogsa her er der foregået ikke ubetydelige forandringer til det bedre, og da navnlig med hensyn til sundhed, bekvemmelighed og hygge. Går vi f. eks. tilbage til det 16. eller 17. århundrede og træder $\mathrm{i}$ tankerne ind $i$ et af husene på landet, vil rort öje allerede på

1) Jf. H. F. Feilberg: „Dansk bondeliv" s. 171-214. 
fremgulvet møde et uvant syn: der er nemlig hverken gulv eller loft, og skönt rummet foruden til forstue tjener til stegers, bryggers og bagers, er der heller ingen skorsten at opdage, men røgen trækker fra ildstedet op under taget, som derfor er kulsort af sod, og finder omsider en udvej igennem den såkaldte lyre, et $\mathbf{i}$ mönningen anbragt firkantet hul med en træramme om. Fra fremgulvet kommer vi ind i piselen, der både er dagligstue og sovekammer. Det mest påfaldende er her den åbne kamin, der udmærker sig ved at sluge en stor mængde bræendsel, og en såkaldt pald, d. v. s. en bænk, der er opsat af ler og kampesten langs hen under vinduerne, samt to vråsenge, hvis uldne lagener, hylsklœeder eller $t j a ̊ l$, man kun plejer at vaske en gang eller to om året. Noget ur er der ikke, men henne i vinduet står både solskive og stoend'glas (timeglas) som repræsentanter for datidens tidsmålere. - I et andet hus fra et noget nærmere liggende tidspunkt ser vi kaminen erstattet af en bilægger, hvorpå der bl. a. findes en gnidesten, nid'sten, en fladrund glat sten til både at male snus og slå kaffebönner i stykker med. På væggene er der anbragt forskellige reoler: en kandebcenk, en tressur og en tavolet eller pirremi (pyramide); og på disse ser vi bl.a. en bortelliedel, en tumling (et lille halvkugleformet bæger uden fod) og en peberkvcern (en slags træmorter med et rivejærn $\mathrm{i}$ bunden $\mathrm{og}$ et andet på enden af støderen). Det er vinter og søndag eftermiddag, hvorfor husmoderen sidder på sin stol med fødderne på en kik eller ståf (et fyrfad med gløder) og skænker kaffe af kedelen, der står på sin fro (en lille 
træbakke, der kan böje sig, når man skænker), medens manden er i færd ned at tænde sin pibe, idet han med fingrene tager en torveglød fra gledepotten og lægger den oven på desetobukken; den sidstnævnte kalder han således, fordi kardusen, den er kommen i fra Holland, har til påskrift: "Dese Toback is te koop by ...." Henne ved vråskabet står "vor fa' $r$ " (bedstefaderen) og pusler: han har faet et hold over den ene hofte, og derfor tager han sig nu en portion teregel (theriak), et universalmiddel, der består af en blanding af 60 - efter andre endogsa 70 - forskellige stoffer med betænksomt hensyn til de enkelte legemsdele og deres sygdomme. Og endelig ser vi "vor mo'r", der netop kommer ind fra e klöw' (kleven 0 : et lille kammer bag ved piselen), hvor hun har gemt sit ungeseg (af lat. ungere 0 : at salve), også kaldet balsambesse og krudthus, d. e. en lugtedåse med duftende urter eller salmiakspiritus $i$, som hun om formiddagen har haft med i kirken for at få sig „et snøk", hver gang hun folte sig $i$ begreb med at bukke under for de sövndyssende elementer i præstens prædiken. Vi går derefter ud i køkkenet, der her er adskilt fra fremgulvet og har fået skorsten, for at tage adskillige genstande, navnlig p̊̊ belysningens område, i öjesyn. Dor er forst fyrtöjet, bestående af fyrstål (tidligere eldjuern) og fyrsten (flintesten) til at slå ild med, samt fyrtonden, en boddike, hvori der er tonder (brændt linned) til at slå ild i; så er der en staend'e eller lysebuk (en rigelig bordhöj lysestage til at stille på gulvet), hvori der sidder et skrcedderlys, der er stabt noget bedre end de sidvanlige pråse, for at skrædderen om 
aftenen kan se ved det; og endelig, hængende på et söm i bjælken, en smadderkat, d. v. s. en lampe, hvis væsentligste del består $i$ en blikkop med tran og en væge af sivmarv $i$; den siges at være brillant til at passe sig selv, men dens evne til at lyse skal være betydelig mindre end dens hang til at ose. Køkkenet er fyldt af en underlig stram, ubehagelig lugt; mon det er fra smadderkatten? Dog nej, den kommer fra lodgryden (farvegryden) henne i skorstenen, en stor sort jydepotte, der indeholder kvindemeje, d. e. gæret urin, som lejlighedsvis skal anvendes både ved farvning og vaskning af uldent og linned.1) - Heller ikke de her nævnte ord kan siges at høre til vort daglige omgangssprog Iængere, og ingen vil nægte, at tabet af flere iblandt dem må tydes som et tegn på forbedrede tider.

Vi vender os dernæst til sådanne ord, der i tidens løb er blevne fortrængte af andre.

Dertil hører på den ene side en hel del nordiske ord, der nu enten er helt uforståelige for de fleste eller dog $\mathrm{i}$ det mindste ikke anvendes længere.

Af disse har nogle måttet vige pladsen for andre hjemlige betegnelser. I ældre danske skrifter støder vi f. eks. jævnlig på navneord som hion, brå, gårdtig, aftenbakke eller natbakke o. s. v., der nu hedder husfolk eller tyende, öjelåg, gårdhund og flagermus; endvidere åstund, bårdag, bang og dvcergemål, der er blevne fortrængte af længsel, slagsmål eller

1) Jf. H. F. Feilberg: Dansk bondeliv s. 15-62, 103 o. fl. 
klø, stöj og genlyd. Af tilsvarende udsagnsord kan nævnes: wtle (overveje), löne (dølge), hode (true), gilje (bejle) og kvcenes (kvindes 0 : gifte sig), minnes (kysses), barjes (slås), orves (nöjes) o. s. v. Andre fortrængte udtryk er endelig: thegen (gavmild), satte (forligte; jf. det endnu brugelige sonderjyske usattes $\mathrm{o}$ : uenige), med lueft (frugtsommelig), e (altid), afleds (borte) og hveden (hvorfra). Det almindelig brugte "madmoder" har nu en noget umage fælle i "familiefaderen“, som atter forgæves søger om en "familiemoder". Tidligere var harmonien bedre, thi "madmoder" havde da ved sin side en madfader (bushonde). Specielt pi sonderjysk grund, hvor jo ellers de gamle betegnelser plejer at holde sig tappert, har navnlig i løbet af det sidste århundrede bl. a. folgende wldgamle ord maittet rige pladsen for andre hjemlige udtryk: udsagnsordene lef' (oldn: leifa), toce'e (oldn: bvætta), he'e (oldn: heita) og liveld' (om månen) er blevne fortrsengte af löwn' (levne), to, bru' (brygge; oldn: brugga 0 : blande, tillave en drik) og stå sild' op, og navneordene dyjlíe, row'le (ruglev), stöwn'daw (stærnedag) og moeld'skjyywt' (muldskjorte) af durik, brød, flytt'daw oy lig'tioj; endvidere bueend af bås, svin'kow' af svinlaj og sej'er af strænge (violinstrænge; deraf formodentlig „sejerværk“ э: slagur, som drives ved lodder og sejer eller snore), samt ols af gilde, ligesom sammensætningerne fie'stel eller lownsol, ar'el og re'sel er vegne, eller i det mindste er stærkt i begreb med at vige for forlowelsgild', begrawels og res'gild, hvorimod "bas'sel“ (barsel 0 : barnsol) står uanfægtet. $\mathrm{Nu}$ aldeles ubekendte hos os er odel for kostald og lejde for remstykke (som spæ- 
rene sidder i); men 1694 skriver en synsmand fra Gram gods bl. a.: „ . . 10 Fag Ødel, som er bygt dertil, ganske brøstfældig for Lejder og Stænger :..."

Andre ord er blevne fortrængte af indforte fremmede udtryk. Her er det navnlig tyske låneord, der er trådte $\mathbf{i}$ steden for de gamle nordiske. Saledes er jarl bleven til hertug, bryde til foged (opr. af lat: advocatus) eller forvalter, mag til svoger, skinder til garver, kiodmanger til slagter, olkun til krokone eller værtinde, mulkedeje til mejerske (plt: meiersch 0 : forstanderinde, femininum til ty: meier; fr: maire, eng: mayer af lat: major; jf. major domus) og endvidere brog til benklæder eller bukser (de sidste oprindelig lavede af "bocksleder"), dïn til lugt, theft til smag, fagring eller fejrende til skönhed, oggen til elendig og jreve til tvivle. Foruden navneordet dön havde man tidligere også det deraf afledede udsaynsord döne, der ligesom det indvandrede "lugte* kunde bruges $i$ betydning af bade at "udsende lugt" og at "opfange lugt", f. eks. „yrthær oc blomster, som nv døner" (De 15 tegn f. dommedag) og ,ieg dön (h)wel, hwat thw stegher" (P. Låle); hos os siger vi jo nu ,, lowt"“, men endnu for en halv snes ar siden traf cand. mag. P. K. Thorsen nede ved det danske sprogs yderste sydgrense, i Fjolde sogn, en gammel kone, der sagde a döen'. På lignende måde har i nyere tid det gamle sønderjyske jerre (edder o: gift) givet tabt for det nymodens blodforgiftning, der er et oversættelseslån fra tysk. Ved tyskernes mellemkomst har vi desuden $\mathbf{i}$ steden for de gamle danske landemarker modtaget de nyere slaviske grænser; jeg siger ved tyskernes „mel- 
lemkomst", thi ,grænse", ty: grenze, er oprindelig ikke noget tysk, men et slavisk ord (russisk: graniza, polsk : granica, tjekkisk: hranice), der er kommet til os over Tyskland. Dog ogsa andre sprog har været med til at undertrykke ord $\mathrm{i}$ vort tungemål; således er genbrev, sivel og röne blevne forjagede af de franske revers eller kvittering, rund (fr: rond) og at prove (jf. fr: épreuve э: forsøg), ligesom styld og tiufned af det formedelst sin endelse halvfranske tyveri. Fra en nyere tid kan anfores, at Rahbeks luftkugle nu hedder luftballon, og at Baggesens troldlygte atter er bleven den latinske laterna magica, samt at de danske lovgivningsmyndigheder 1888 i en bestemt hensigt lod det nydannede danske ord kunstsmör fortrænges af det udenlandske margarine.

På den anden side er imidlertid også et stort antal fremmedord blevne fortrængte af sproget.

I dette tilfælde er det bovedsagelig hjemlige betegnelser, der har formået at göre sig gældende, og navnlig da over for den vældige mængde af indtrængte höjtyske ord, der fra det 17. århundrede af gennem lange tider oversvømmede Danmark. Som eksempler især fra det 17. århundrede kan nævnes groppenbrad eller groffenbrad, krebs (det gamle ligorm), fukssvandser, golegenhed og digte, der senere er blevne afleste af grydesteg, kræft, smigrer eller slesker, lejlighed og tætte. I det 18. århundrede moder vi ligeledes, selv hos de bedste forfattere, stadigvæk tyske eller tyskagtige orddannelser, som $\mathrm{f}$. eks. underdan, bakkens afhang, kortvillig, eng, gelinge, afvarte, emphange, grysse, skiertse o. s. v., der jo nu er fortrængte af de danske 
undersåt, skråning, morsom, snæver, lykkes, afvente, modtage, hilse og skemte. Også helt uforklædte tyske ord som meuchelmorder og lesterhuft kan man finde; nu siger vi jo snigmorder og brødefuld. Ja selv hos det 19. århundredes ældre forfattere træfter vi den slags og lignende fortyskninger, såsom yestult, suts, vederdaber, sterrbo, immer, begegne, bemäje o. 1.; men også disse har omsider, om end for det meste forst temmelig sent, måttet vige tilbage for hjemlige betegnelser, nemlig: skikkelse, sætning, gendøber, dødsbo, altid, at møde, at umage (ulejlige) o. s. v. H. C. Ørsted har fjærnet det efter tysk mønster dannede rimingsmolstand ved at indfore det danske gnidningsmodstand, Chr. Molbech har fordrevet det ligefrem tyske yebet med det nordiske (svenske) område, og den danske rigsdagstidende, der i begyndelsen udkom med anhuny, har siden 1863 fahet et tillæg. Foruden de nævnte og talrige andre tyske udtryk er ogsa en hel del franske ord, der navnlig i sidste halvdel af 17. århundrede brugtes i finere krese i Danmark, efterhånden forsvundne af sproget, idet hjemlige udtryk er trådte $i$ stedet. Hvor udstrakt $i$ sin tid brugen af franske ord har været, vil man bedst kunne skönne ved at læse følgende to sætninger af Johan Monrads selvbiografi fra ca. 1690: „Jeg kunde dog nogenledisz fournere till dend agreable conrersution, agreable maa Jeg well sige, thi Jeg remurquerede i ald Jomfru Mette Sophia Kralbesz discours den Gudsz Frygt, den dyd, dend innocenre, dend esprit och hoflighed, att Jeg i sandhed motte høre dett an med forundring. Hindis person och trille syntis mig dend allerrrmentupionseste af alle de Jeg hafde seett, hindis 
maaneer att klæde sig paa saa rijg och saa well choiseret, att Jeg hafde well intett tencht att fundett saadan noget $i$ disse lande." Som enhver vil se, har de fleste af de ved skråskrift fremhævede ord nu ikke nogen borgerret $\mathrm{i}$ sproget længere; de har $\mathrm{i}$ tidens lob måttet vige pladsen for folgende mere forstăelige udtryk: $y$ de med til (bidrage), behagelige, samtale, behagelig, lagde mærke til, tale, uskyldighed, åndrighed, vækst (figur), allerfortrinligste og udsøgt.

Men også adskillige f r em mede betegnelser har været med til at fordrive en del af de tidligere indvandrere. Således er enkelte tyske ord blevne afloste af andre udenlandske, som onyefcer af det oprindelig ligeledes tyske omtrent (sammendraget af „umme den trent" 0 : om skiven), bisloperske af det franske maitresse (ved siden af det danske frille), vilugen af det italienske gardin (ital: cortina) og ivgong af det græske labyrint (gr: labyrinthos). På samme måde har flere franske betegnelser måttet vige pladsen for andre fremmede, som bonnet for det ligeledes franske kasket (fr: casquette), bomluarde for det italienske resp. franske kanon (ital: cannone, fr: canon, af lat: canna $\rho$ : ror) og brarale for det tyskagtige trods (ty: trotz). Og endelig er ogs̊̊ gamle latinske udtryk blevne trangte tilbage af nyere indvandrere, som f. eks. stil (lat: stilus) af det græsk-latinsk-tyske griffel (gr: grapheion, lat: graphiolum, ty: griffel), suter (lat: sutor) af det tyske skomager og salse eller salsament (lat: salsamentum) af det franske sovs (fr: sauce), såfremt man da ikke foretrækker det danske djppelse, eller som vi her $i$ Nordslesvig: du'els. 
Tabet af et ord er imidlertid ikke nogen pludselig overgangsakt, men en mere eller nindre langsom proces, og det vil derfor ofte være vanskeligt at afgöre, om et ord er helt forsvundet af sproget eller blot bør regnes til de delvis tabte. For de sidstnævntes vedkommende må vi i korthed omtale to forskellige tilfælde.

$P_{\mathfrak{C}}$ den ene side kan det delvise tab af et ord besta $\mathbf{j}$ en ligefrem indskrænkning af det $\mathrm{ydre}$ område. Vi har jo f. eks. set, at et ord som döne i betydning af "lugte“, skönt længe fortrængt af almindelig sprogbrug, har holdt sig hist nede ved sproggræensen helt indtil vore dağe. $\mathrm{Og}$ på lignende måde er det gået med en hel del andre. Således f. eks. med det gamle biord rad (oldn: hraða $ว$ : hurtig, skyndsomt), der bl. a. forekommer flere gange i „Den danske rimkrönike": "twingdæ ieg i ghen saa rath", "togh theres søsther fran them fwll rath" o. s. v.; i vore dage er det ukendt af de fleste, men det haves dog endnu i det sundevedske raj, f. eks.: „han è raj blöwn fær're“, „kan do kom raj egjen?, d. v. s. „han er hurtig bleven færdig", „,kan du komme snart igen ?:" o. s. v. Eller tager vi et udtryk som det gamle $i$ adens (oldn: aðan 0 : for kort siden, nylig). Endnu i Kristjan den førstes diplomatarium hedder det: „som $\mathrm{i}$ stodhe. her $i$ athens", og $\mathbf{i}$ et romantisk digt fra middelalderen: "tw trwged fasst $i$ iadans". $\mathrm{Nu}$ er udtrykket tabt $\mathrm{i}$ de fleste egne af Danmark, men det bruges jo dog endnu hos os i den sammentrukne form ejåns', ligesom man på svensk siger ijjåns, medens det på færøisk stadig hedder $i$ aðan. Og ligesom et ord 
kan forsvinde fra visse egne og samtidig holde sig i andre, således kan en betegnelse ogs丸 gå delvis tabt ved at udgå af enkelte samfundskrese. Det tidligere ganske almindelige geborsda (geburtsdag) f. eks. har nu kun hjemme i de lavere klasser i Danmark, medens det $\mathbf{i}$ mere dannede krese er blevet fortrængt af det danske fodselsdag. En dannet dame taler i vor tid ikke om sin sterk og sine bukser; de er blevne til hendes chemise og benklæder eller permissioner. Omvendt er ordet fjene til dels fortrængt fra de mindre dannede kvinders og da navnlig tjenestepigernes sprog, hvad dør vistnok bedst kan belyses ved folgende korte, fra et ugeblad hentede samtale: "Hvor tjener De nu, Line? - „Undskyld, bedste frue - jeg tjener ikke jeg konditionerer hos oberst Snabel, og han tjener ved husarerne." Imidlertid horer dette sidste eksempel måske snarere til den næste klasse.

$\mathrm{På}$ den anden side kan der nemlig også forega et delvist tab af ord med hensyn til deres oprindelige in $\mathbf{d r}$ e beskaffenhed : indholdet. Dette har bl. a. været tilfældet med ord som spisevært og værtshus. En nutidens finere restavrator vilde næppe synes om at høre sig til- eller omtalt som spisectert; ordet minder for meget om svende, soldater og droskekuske. Tidligere derimod knyttede man ikke nogen lavere forestilling til denne betegnelse: endnu 1792 skrev Fr. Sneedorf fra Paris, at han gik til "en spisercert, eller, som han her kaldes meget uegentlig, restaurateur." Eller hvilken hotelejer vilde ikke blive meget fornærmet, ni̊r man kaldte hans ejendom et rertshus?' Og dog er det ikke et århundrede siden, at denne betegnelse 
brugtes almindelig selv om det fineste hotel. Et par andre eksempler pa kvalitativ indskrænkning har vi $\mathbf{j}$ ordene ble og os. Med en ble betegnedes tidligere overalt i Danmark det samme som endnu hos os $i$ Nordslesvig, nemlig et „lagen“; men i almindeligt dansk er jo ordet nu blevet indskrænket til at være navnet på et lagen for börn $\mathbf{j}$ den spædeste alder. Og os var i tidligere tider den almindelige danske betegnelse for det, vi nu kalder "saft". Henrik Harpestreng skriver f. eks. $i$ den ene af sine urtebøger: „Fænikæl root stampæth oc osæen blændæth mæth hunugh, thæt hiælpær øghn af alt skymæl, of the smøræs oftæ thær mæth", og endnu i Tidemands postil fra 1564 hedder det: "Naar Træ faa Oess og Blad." I denne sammenhæng er ordet nu fremmed for os; og dog er det ikke fuldstændig tabt på det næunte begrebsområde: i vort sønderjyske landsmål er jo os endnu navnet p\& det snevrere begreb „tobakssaft". Og så til slutning endnu et par særlige tilfælde. I en af Kristjan Falsters satirer hedder det bl. a.:

\section{da spilles hurtig kortenspil, \\ labet, skjervensel, lanter.}

Af de tre sidstnæunte ord har kun det mellemste holdt sig $\mathrm{i}$ videre krese til vore dage som navn på et kortspil. Men tidligere var ogsi de to andre aldeles almindelige som sådanne. Labet er det franske la bête, der egentlig betyder "fæ" og altså var overfort på det pågældende kortspil af mere forklarligt end netop overmåde hofligt hensyn til den tabende spiller. Selve spillet kendes vel nu næppe mere; og med dette er også ordet gi̊et næsten aldeles af brug, men dog ikke fuldstændig: det 
kan endnu stadig anvendes for at betegne begrebet "udnattet, træt" eller lignende. Det ejendommelige herved ligger altså $i$, at der først er foregået en udvidelse af ordets værdi, og at derefter ordet $i$ sin oprindelige betydning er gået $\mathbf{i}$ glemme, hvorimod det i sin overforte egenskab delvis er blevet bestående. Og det samme har været tilfældet med ordet lanter, om end på en made med den modsatte virkning. Hos Holberg f. eks findes dette udtryk som navn på et kortspil jævnlig; således bl. a. i „Peder Pårs": „kan I spille en Lanter med Eders Dotter Nille“, i „Henrich og Pernille": "Jeg er bange, at han sidder der udi en Lanter til Ørene", o. s. v. Heller ikke dette kortspil kan regnes til de almindelige $i$ vore dage, og ordet er vistnok forsvundet af sproget i de fleste egne af Danmark; men i Nordslesvig siges der endnu om én, der har haft en betydelig vinding, har gjort „et ordentligt kup": „han hæ gøer en orndle lander". Ordet er altså forst blevet overfort fra kortspillet på den med dette eventuelt forbundne vinding og dernist, efter at spillet var gået af brug, blevet indskrænket til at betegne en særlig ,af lykken afhængig vinding" alene.

Men under disse betragtninger er vi allerede komne ind over grænsen mellem dette og det næste kapitels naturlige område.

(Fortsættes.) 